\title{
The Political Cycle of Road Traffic Accidents*
}

\author{
Paola Bertoli \\ University of Economics, Prague \\ CERGE-EI Fellow ${ }^{\dagger}$
}

\author{
Veronica Grembi \\ University of Milan
}

University of Economics, Prague

UPDATED VERSION — July 2019

\begin{abstract}
Road traffic accidents mean lost productivity and medical expenditures. We explain trends in traffic accidents as a function of the political cycle using municipal data from Italy. We show that during municipal election years, the accident rate increases by $1.5 \%$, with a $2 \%$ increase in the injury rate but no effect on the fatality rate. The effects are stronger in the two quarters prior to the election quarter, when the electoral campaign is at its zenith, and in the second quarter after the election, when the elected mayor takes office. We argue that this is the result of a decrease in ticket rates during election years, while expenditures in road safety increases. Our results are robustly driven by the municipal political cycle defined in different ways, and their magnitude and direction are not explained by spillover effects between municipalities. Proximity to a national police station reduces the impact of local elections on injury rates.
\end{abstract}

JEL Classification: H70, H75, D72

Keywords: Road Traffic Accidents, Political Cycle, Municipalities, Elections

*We thank the participants at the seminar at the Leibniz Institute for East and Southeast European Studies (Regensburg); the University of Economics, Prague; the 2019 European Public Choice Annual Conference (Hebrew University); and the 9th European Meeting of the Urban Economics Association (Amsterdam) for their comments and suggestions on previous versions of this paper. The current version of the paper provides new evidence with respect to the previously circulated WP (CERGE-EI WP 633/2018). We would like to thank Giulia Mugellini (Polis-Lombardia) and Diego Gasperini (Ufficio di Statistica della Regione del Veneto) for providing us with the traffic accident data on Lombardy and Veneto, as well as The Linh Bao Nguyen and Sofia Terragni for their excellent work as our research assistants.

${ }^{\dagger}$ CERGE-EI, a joint workplace of Charles University and the Economics Institute of the Czech Academy of Sciences, Politickych veznu 7, P.O. Box 882, 11121 Prague 1, Czech Republic. 


\section{Introduction}

Road traffic accidents are the main cause of mortality among people under age 45 and the leading cause for those between 15 and 29 (Eurostat, 2015). While there are more than 1.25 million deaths each year on the roads, between 20 and 50 million more people suffer nonfatal injuries, which can result in temporary or permanent disabilities (WHO, 2015). The economic losses are substantial both individually and nationwide: most countries are estimated to lose approximately $3 \%$ of their GDP in lost productivity and medical expenditures (WHO, 2015), which does not include the costs of traffic congestion and fuel waste associated with traffic accidents. As a result, reducing traffic accidents is a top priority of policy makers: the 2030 United Nations Agenda for Sustainable Development includes halving the global number of road accidents among its targets. Different levels of government can play crucial roles in promoting this ambitious plan, which requires both effective traffic safety regulations and enforcement. National governments are often responsible for regulating the consumption of alcohol and the use of seat belts, child restraints, and helmets. Local governments and authorities play a tremendous role in road maintenance and direct law enforcement. Although the literature is rich on the impact of general safety measures on traffic accidents and fatalities (e.g., Cohen and Leinav, 2003; Bourgeon and Picard, 2007; Adams and Cotti, 2008; Abouk and Adams, 2013), evidence on the role of local governments is scant and based primarily on the channel of corruption in developing countries (Bertrand et al., 2007; Anbarci et al., 2006; Law et al., 2009; Albalate and Yarygina, 2017; Wales, 2017).

We focus on the role of local governments in a developed country to assess if and how the municipal political cycle affects traffic accidents and their consequences, namely, injuries and deaths. In many countries, citizens elect local authorities and, in some cases, as in the US, even local police officers. Hence, distortions associated with the political cycle might affect trends in traffic accidents by influencing law enforcement patterns at the local level. For instance, as elections approach, local politicians might want to show a strong commitment to fighting traffic accidents and increasing traffic safety, so we might expect a lower incidence of accidents in election years. On the other hand, incentives for strict law enforcement might be lower in election years since strict law enforcement might displease myopic voters, reducing political support. Voters are generally pleased with measures to fight crime while regarding a parking violation or the sending of audio messages while driving not a crime.

By exploiting staggered municipal mayoral elections from 1995 to 2016 in almost 2000 municipalities in two Italian regions - Lombardy and Veneto (representing $26.10 \%$ of all Italian municipalities and counting $15,000,000$ inhabitants) - we show, that in municipal election years, the number of traffic accidents with at least one injured per 1,000 residents increases by $1.5 \%$ at the mean of traffic accidents. According to a back-of-the-envelope calculation based on a benchmark case (Section 3.2), the estimated total loss per resident is approximately 3 (2018) euros per election. We show that the main channel of this effect is a reduction in traffic tickets levied in election years. Using descriptive data on the type of tickets we recovered through the yearly reports of local police activities for a small sample of municipalities, we show that during electoral years, the incidence of tickets on serious violations does not change (speed violations and driving under the influence of drugs and/or alcohol), most likely associated with severe accidents. However, parking tickets and tickets for overall minor violations decrease (Table A.3.

We provide evidence that while the incidence of tickets decreases, expenditures on road safety/ maintenance increase. This evidence explains our finding that while the injury rate (i.e., the number of injured per 1,000 residents) increases by $2 \%$, the municipal political cycle has no impact on the fatality rate (i.e., the number of deaths per 1,000 residents). Pleasing voters is good, but deaths on the roads are bad. We support this finding by showing the types of accidents that increase the most are daytime and rush hours 
accidents as well as those occurring under good weather conditions. By contrast, the political cycle has no effect on on the most severe types of accidents, which are those occurring at night or on weekends.

Our baseline results are robust to different specifications of the municipal political cycle and to trends at the provincial (i.e., commuting routes) and local labor market level (i.e., employment rates) to exclude the possibility that the election year effect is due to a change in the likelihood of driving more (as in Parry, 2004; Miller et al. 2009; Bertoli et al. 2018; Giulietti et al., 2018) rather than changes in law enforcement, as we argue. Our findings are also robust to controlling for spatial dependence in the error term due to unmeasured factors correlated across space and affecting the frequency and severity of road crashes (e.g., traffic spillovers). Additionally, we show that alternative ways of improving road safety without targeting drivers, such as increasing the number of lights and public electricity consumption (measured in kilowatts per hour), do not follow the cycle of ticket rates and road safety/maintenance expenditures.

By exploiting quarter-level data to provide insight into developments during an election year (Akhmedov and Zhuraskaya, 2004), we show that increases in accident and injury rates are stronger during the two quarters preceding the electoral quarter, when the electoral stakes are higher, and in the second quarter following the election, when an elected mayor operationally begins serving her term. We run placebo tests, using the quarter of elections in fake electoral years (year +2 and +3 from the election year), which prove the robustness of our results.

We investigate whether part of the estimated effect could be explained as a function of other political cycles, such as those linked to national elections or to the political cycles of neighboring municipalities. The national political cycle coincides with the mayoral cycle for only $11 \%$ of our observed elections, and it produces effects in the direction opposite to mayoral elections. National election years have a negative and statistically significant impact on accident, injury, and fatality rates. If anything, this cycle reduces the effects we estimate. However, the results on fatality rates are the only ones robust to the introduction of provincial fixed effects and trends. We do not find significant spillover effects from elections in neighboring municipalities.

Finally, we analyze how a set of political and nonpolitical municipal characteristics channel the election year effect. We find that the positive impact of the political cycle on the injury rate increases as the political environment becomes more competitive, as proxied by a higher number of candidates. A similar effect is observed when politicians are not elected through a runoff system. The estimated effect is no different in a constituency with higher trust in local governments, as measured by the results of a referendum on more autonomy or candidates facing term limits. The result on term limits can be explained by the fact that incumbent term-limited mayors might want to support their own political party or candidate or might seek to be supported in other electoral offices, among other things (Gagliarducci and Nannicini 2013; Gamalerio, 2019). Regarding the nonpolitical municipal characteristics, we estimate a stronger positive effect of the cycle when the distance to the nearest national police station is greater, in smaller municipalities, or in municipalities that do not participate in municipal consortia to provide local services. When the municipality counts fewer registered vehicles, no differential effects result.

Our paper also relates to the strand of literature on the strategic behavior of politicians throughout an electoral cycle. Even though evidence on the link between the political cycle and fiscal policy is vast (Persson and Tabellini, 2002; Shi and Svensson, 2002; Brender and Drazen, 2005), scant attention has been devoted to whether an incumbent's strategic behaviors spill over to other domains of public policy, especially at the local level $L^{1}$ Among the few exceptions are Englmaier and Stowasser (2017), who find

\footnotetext{
${ }^{1}$ Evidence is widespread on political cycles within countries, including Akhmedov and Zhuravskaya (2004) - Russia; Gonzalez (2000) - Mexico; Cole (2009)- India; Drazen and Eslava (2010) - Colombia; Foremny and Riedel (2014)- Germany;
} 
that lending policies strategically respond to local elections at the county level in Germany, and Baskaran et al. (2015), who provide evidence of an electoral cycle in electricity service provision in Indian states. Closely related to the analysis of the public policy cycle at the local level is the work of Takako and Bessho (2018) on the employment of physicians in Japanese public hospitals, which increases in municipal election years, in line with findings for France by Clark and Milcent (2011) and for the US by Bee and Moultun (2015). Regarding the Italian case, our evidence on the municipal political cycle affecting traffic tickets has been confirmed by Bracco (2018). Bracco (2018) uses budget data from all Italian municipalities to show that in the electoral year, captured by a dummy for the election year and the year before the election, tickets decrease. However, Bracco (2018) does not connect the cycle to traffic accidents, to their consequences, or to other electoral cycles (i.e., national). Because of these substantial differences, our contribution provides insights into the consequences of the political cycle on health and raises concerns on the multilevel governance of services related to public safety in a decentralized institutional framework.

The paper is organized as follows. Section 2 provides some background information on the electoral system and the dataset employed. Section 3 defines the empirical strategy and robustness checks and discusses the results. Section 4 concludes.

\section{Institutions and Data}

Our sample is based on the municipalities of two northern Italian regions: Lombardy and Veneto. For at least two reasons, we restrict our focus to these regions: the type and representativeness of their data on traffic accidents and their homogeneity in terms of social capital. First, Veneto and Lombardy count a remarkable number of municipalities: jointly 2,110, accounting for a quarter of all Italian municipalities, which include almost 15,000,000 inhabitants. Second, they provide information at the municipal level not only on the number and severity of traffic accidents but also on the conditions under which accidents occur (e.g., the number and severity of accidents per weather condition or per time of the day). This information is otherwise not available, but it is valuable since certain types of accidents, such as those occurring at night and on weekends, are regarded as more severe than others. Even more relevant for our goals is the fact that these two regions provide accident data (i.e., only the overall number of accidents, injured, and deaths) at the quarterly level, which allows us to offer a better understanding of the dynamics during an election year.

Belonging to the northern part of the country (Figure A.1, both Lombardy and Veneto have high levels of social capital (Stella et al., 2013). General compliance with the law, specifically with road safety laws, is strong in both regions and higher than in other parts of Italy. For instance, the incidence of seat belt use is $93 \%$ in Lombardy and $92 \%$ in Veneto. Similarly, they both report among the lowest tax evasion rates in the country (below 13\%, while, for example, Campania and Calabria are above 20\%) (Confcommercio, 2017). Their high standards of law enforcement allow us to generalize the findings from this institutional setting without serious concerns that corruption or weak institutional design, as addressed by the literature on developing countries, might play a significant role.

\subsection{Accidents}

Italian municipalities manage approximately $10 \%$ of total public expenditures and are responsible for a wide range of services, including water supply, waste management, municipal police, infrastructure, welfare, and housing (Grembi et al. 2017). Specifically, they supervise the maintenance of over $62 \%$ of and Alesina and Paradisi (2017) - Italy. 
the national transport network (SITEB 2012). Mayors directly oversee the activities of local police forces, which are primarily responsible for the enforcement of traffic laws at the local level, together with the national police, the so-called Carabinieri $2^{2}$ Figure 1 shows the geographical distribution of national and local police stations at the municipal level in our sample.

\section{Figure 1: Distribution of national and local police}
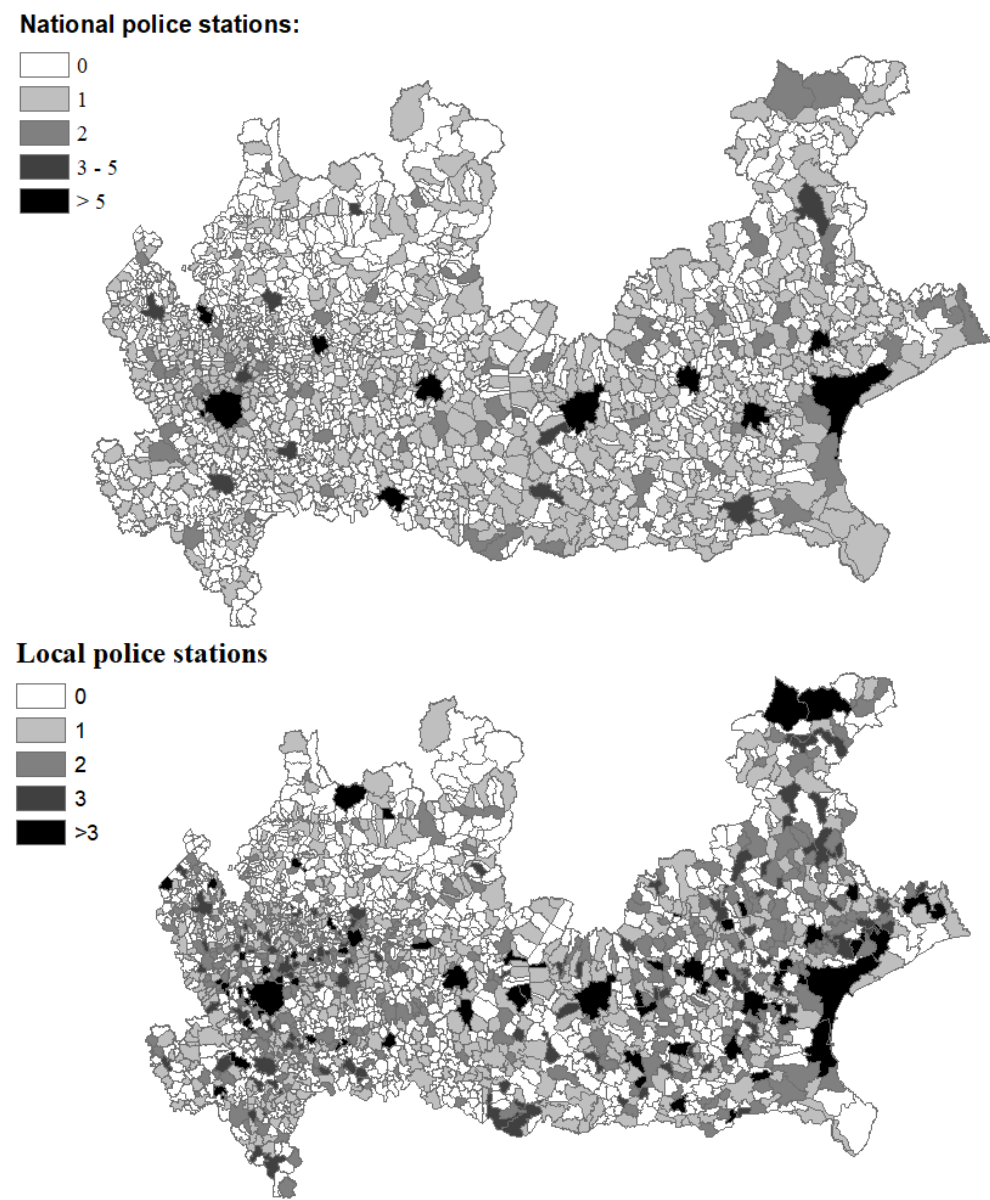

Notes: The upper map shows the distribution of national police stations among municipalities in Lombardy and Veneto, while the lower map shows the distribution of local police stations. In both cases, when an area is darker, it has more stations.

We recover municipal data on the number of accidents and on the number of injured persons and deaths per accident for the periods of 1995-2016 for Veneto and 2000-2016 for Lombardy. These data refer to accidents with at least an injured person and, as such, they are recorded through the police system and collected by the National Institute of Statistics (ISTAT). Hence, our dataset does not include accidents with no casualties, which might be considered as those more endogenously reported 3 In an accident with a casualty (more or less severe), police intervention is preceded by a call to the emergency number, which in Italy is $1124^{4}$

\footnotetext{
${ }^{2}$ Other police forces (i.e., Polizia di Stato) operate only in larger municipalities.

${ }^{3}$ Based on the small sample of municipalities that provided information on the type of tickets, accidents with no injured account for $44 \%$ of the total number of yearly reported accidents.

${ }^{4}$ We recovered information on emergency calls related to road traffic accidents only for Lombardy from 2008 to 2016 , with the support of the regional agency for emergencies that manages the 112 service. Figure A.2 shows the correlation between emergency calls and accidents as reported in our dataset. As expected, the correlation is perfect and positive
} 
Based on these data, we create three main outcomes of interest: Accident rate, Injury rate, and Fatality rate. These outcomes are calculated as the number of accidents, injured persons, and deaths per 1,000 residents 5 We also calculate the rate of accidents, injured persons, and fatalities per type of accident, defined as accidents during rush hours (7-9 am and 5-8 pm), during the day, at night, on weekends, and under good weather conditions. These outcomes allow us to check whether the composition of accidents changes due to the election year.

\section{$2.2 \quad$ Elections}

Since 1993, Italian mayors have been directly elected through a runoff system in cities with more than 15,000 inhabitants and through a single-round plurality rule in those with fewer than 15,000 inhabitants. Mayoral elections are held jointly with elections of municipal councils (i.e., Consigli Comunali), and by Law n. 182, 7 June 1991, they must be held on a Sunday between April 15 and June 15 if the mayor's mandate ends in the first half of the year (January-June) or in the same period of the following year if the mandate ends in the second semester (July-December). Hence, elections are held in a staggered way across municipalities. Mayors used to serve a 4-year term, which was extended to 5 years in 2001, and they face a two-term limit. However, several exceptions to this two-term limit have been implemented over time for municipalities with less than 3,000 inhabitants 6 The most recent change was introduced in 2014 (Law 56/2014), when the term limit was extended to 3 consecutive terms.

From the Italian Ministry of the Interior, we collected national and municipal electoral data for a total of 7,837 municipal elections, distributed as shown in Figure 2. From the same source, we also recovered information on municipal budget items, such as revenues from traffic tickets, expenditures on police and on road safety, the yearly number of lights used and annual kilowatt-hour public electricity consumption. Using the budget items, we construct Ticket rate, which is equal to the number of traffic fines issued by the local police per 1,000 resident population, and Ticket revenues, which is the log of per capita traffic ticket revenues. In addition, Police expenditures and Road safety expenditures represent the $\log$ of per capita expenditures on local police and on road safety. A more comprehensive explanation of the variables is available in Table A.1. Since for most of these budget items, the values for very small municipalities are systematically zero, we provide the baseline results on the entire sample; then, we focus on the sample of municipalities with more than 1,000 inhabitants ( $82 \%$ of the full sample) to make the analysis more meaningful $[7$ This procedure means that our final sample analyzes 6,592 elections. Finally, basic municipal characteristics such as the municipal area, altitude, and population were taken from the Italian Institute of Statistics (ISTAT).

between the two measures. The figure also highlights the main characteristic of the emergency calls dataset: the same accident results in several calls.

${ }^{5}$ According to international standards, a traffic death is registered up to 30 days after the accident.

${ }^{6}$ Exceptions were allowed because for very small municipalities, finding suitable candidates is not always simple.

${ }^{7}$ Figure A.3 in the appendix shows the distribution of municipalities with more than 1,000 residents, while Figure A.4 shows the population density at the municipal level. The municipalities we drop in our preferred sample are also those with a lower population density. 
Figure 2: Distribution of mayoral elections from 1995 to 2016

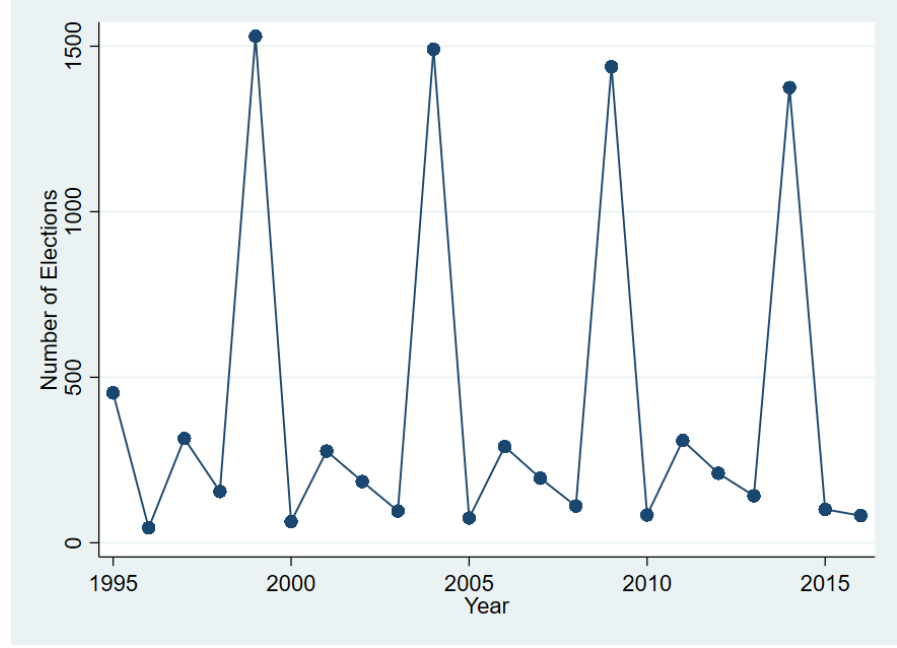

Notes: The graph shows the number of municipalities per year holding a mayoral election in Lombardy and Veneto during our observation period (1995-2016).

\section{Empirical Analysis}

\subsection{Baseline}

Several approaches are applied in the literature to assess the role of the political cycle: the standard approach is the use of an election year dummy (Shi and Svensson, 2000; Cole, 2009; Baskaran et al. 2015; Bee and Moulton, 2015; Alesina and Paradisi, 2017). Consistently, we exploit the panel dimension of our dataset and we estimate a panel fixed effects model at the municipal $(m)$ year $(t)$ level as described by equation 1 .

$$
\text { Outcome }_{m t}=\beta \text { Election year }+\rho_{m}+\gamma_{t}+\pi \text { pop_density }{ }_{m t}+\epsilon_{p}
$$

where $\rho_{m}$ are municipality fixed effects, $\gamma_{t}$ are the year fixed effects to capture common shocks (e.g., fluctuations in the price of gasoline), and Election year is a dummy equal to 1 for a municipal election year. Not many time invariant variables can cover the entire observational period, so we used population density, which is correlated with both the rate and severity of accidents. While Equation 1 describes our preferred specification, we also test the model in Equation 2

$$
\text { Outcome }_{m t}=\beta \text { Election year }+\rho_{l l m}+\gamma_{t}+\pi p o p_{-} \text {density } m+T I^{\prime} \sigma+\epsilon_{p}
$$

In this second model, we use fixed effects for the local labor market systems to capture the commuting patterns and the labor market dynamics of residents, and we proxy them in two ways: using provincial fixed effects (12 provinces in Lombardy and 7 in Veneto) and using the local labor market units as produced by the national institute of statistics (57 units in Lombardy and 49 in Veneto) $8 I_{m}^{\prime}$ groups the municipal time-invariant characteristics (e.g., altitude and whether the municipality is coastal), which

\footnotetext{
${ }^{8}$ We use both because the classification of the local labor market systems changed during our observational period, and the provincial level is considered a proper alternative.
} 
might affect the probability of having an accident and its severity, as well as the presence of a local and a national police station. For both models the standard errors are clustered at the provincial level to cope with serial correlation problems. The outcomes include both the rates generated using the accident data and the measures based on budget items.

\subsection{Baseline Results}

Table 1 reports the baseline results. For each outcome, we estimate 2 specifications for the three models. In Panel A, we present the results for the municipal fixed effects model, and the first column of each outcome is the coefficient of the election year estimated without time varying controls. Hence, the second column is our preferred specification ((2), (4), and (6)). In Panels B and C, instead of using the municipal fixed effects, we use the provincial fixed effects (B) and the local labor market fixed effects (C). For these models, in the second column we include population density and time invariant controls, such as the number of local and national police stations, altitude and whether the municipality is coastal.

The election year has a positive and significant effect on both accident and injury rates in each specification, even though the fatality rate is never affected. According to our preferred specification, for election years we estimate a $1.5 \%$ increase in the accident rate and approximately a $2 \%$ increase in the injury rate at the mean of each variable $!^{9}$ The results are confirmed also by the models with provincial and local labor market fixed effects, in which we account for the labor commuting patterns: the magnitude slightly increases, with a $+2.2 \%$ impact and a $+2.5 \%$ impact on the accident rate, respectively, and no consequences on the fatality rate.

A monetary assessment of the increase in accident and injury rates is difficult to provide. To perform some back-of-the-envelope calculations, we use a benchmark case provided by a 2012 Ministry of Infrastructures and Transport report (Regione Veneto 2014) estimating the overall average cost of a traffic accident as 58,926 euros (2018 euros). This amount can be broken down into personal costs due to injuries (46,759 euros) and economic/administrative costs (12,167 euros). Our baseline result estimates an increase of approximately 0.06 accidents (per 1,000 inhabitants), which means an overall additional cost of 3,073 euros, or 3 euros per capita per election. For a municipality with 5,000 inhabitants, this estimate translates to 15,000 euros for accidents only. Expanding this amount to approximately 2,000 municipalities, it translates to 30 million euros per election. This number is a lower bound of the actual expenditures triggered by the increase in accidents because we do not include accidents with no victims or, for instance, any associated increase in traffic congestion.

We argue the main driver of our baseline results is the change in the tickets triggered by the electoral cycle. When we plot the coefficients of the election year on the budget items, as in Figure 3 both the ticket rate and revenues decrease, while road safety expenditures increase and expenditures on local police do not. These findings are consistent with our observations using the information, available only for Lombardy, on the police force submitting the accident reports. While tickets are a target-oriented approach to road safety, road maintenance targets drivers and the community overall. Road safety might be increased other ways, for which the potential beneficiaries are not targetable and the target is the overall community, for instance, by increasing the number of lights on the streets. Hence, we check the impact of the election year on the number of lights and the number of public kilowatts consumed per hour (both normalized to the resident population), and we do not detect any effect of the election year.

To dig into the potential composition effect on traffic tickets, we collected online reports on the

\footnotetext{
${ }^{9}$ These results stem from the sample with municipalities larger than 1,000 inhabitants. However, they are confirmed in the sample containing all municipalities, as shown in Table A.2 in the appendix.
} 
activities of the local police since there is no national database of local police tickets per municipality and year. We focus on two groups of tickets: tickets for Minor and Serious violations. Minor violations refer mainly to parking violations and driving in traffic zones restricted only to drivers with permits, while Serious violations refer to driving under the influence of drugs or alcohol and to speed violations and are generally perceived as life-threatening behaviors. For a few municipalities we also have the number of kilometers registered each year by the police patrols, which could capture an increase in the intensity of activity during an electoral year. As reported in Table A.3, during the electoral year Minor violations decrease, driven mainly by lower parking tickets 10

Table 1: Road traffic accidents: baseline results

\begin{tabular}{|c|c|c|c|c|c|c|}
\hline & \multicolumn{2}{|c|}{ Accident rate } & \multicolumn{2}{|c|}{ Injury rate } & \multicolumn{2}{|c|}{ Fatality rate } \\
\hline & (1) & $(2)$ & (3) & (4) & (5) & (6) \\
\hline \multicolumn{7}{|c|}{ PANEL A: Municipal FE } \\
\hline Election Year & $\begin{array}{l}0.040^{*} \\
(0.020)\end{array}$ & $\begin{array}{c}0.040^{* *} \\
(0.020)\end{array}$ & $\begin{array}{c}0.076 * * \\
(0.030)\end{array}$ & $\begin{array}{c}0.075^{* *} \\
(0.030)\end{array}$ & $\begin{array}{c}0.004 \\
(0.003)\end{array}$ & $\begin{array}{c}0.004 \\
(0.003)\end{array}$ \\
\hline Pop Density & No & Yes & No & Yes & No & Yes \\
\hline Year FE & Yes & Yes & Yes & Yes & Yes & Yes \\
\hline Observations & 31,916 & 31,909 & 31,916 & 31,909 & 31,916 & 31,909 \\
\hline Mean & 2.625 & 2.623 & 3.808 & 3.806 & 0.111 & 0.111 \\
\hline \multicolumn{7}{|c|}{ PANEL B: Provincial FE } \\
\hline Election Year & $\begin{array}{c}0.065^{* * * *} \\
(0.020)\end{array}$ & $\begin{array}{c}0.058^{* * *} \\
(0.020)\end{array}$ & $\begin{array}{c}0.105^{* * *} \\
(0.032)\end{array}$ & $\begin{array}{c}0.095^{* * *} \\
(0.032)\end{array}$ & $\begin{array}{c}0.004 \\
(0.003)\end{array}$ & $\begin{array}{c}0.004 \\
(0.003)\end{array}$ \\
\hline Pop Density & No & Yes & No & Yes & No & Yes \\
\hline TI Controls & No & Yes & No & Yes & No & Yes \\
\hline Year FE & Yes & Yes & Yes & Yes & Yes & Yes \\
\hline Observations & 31,916 & 31,870 & 31,916 & 31,870 & 31,916 & 31,870 \\
\hline Mean & 2.625 & 2.623 & 3.808 & 3.806 & 0.111 & 0.111 \\
\hline \multicolumn{7}{|c|}{ PANEL C: LLM FE } \\
\hline Election Year & $\begin{array}{c}0.063^{* * *} * \\
(0.019)\end{array}$ & $\begin{array}{c}0.058^{* * *} \\
(0.019)\end{array}$ & $\begin{array}{c}0.102^{* * * *} \\
(0.033)\end{array}$ & $\begin{array}{c}0.095^{* * * *} \\
(0.033)\end{array}$ & $\begin{array}{c}0.004 \\
(0.003)\end{array}$ & $\begin{array}{c}0.004 \\
(0.003)\end{array}$ \\
\hline Pop Density & No & Yes & No & Yes & No & Yes \\
\hline TI Controls & No & Yes & No & Yes & No & Yes \\
\hline Year FE & Yes & Yes & Yes & Yes & Yes & Yes \\
\hline Observations & 31,916 & 31,870 & 31,916 & 31,870 & 31,916 & 31,870 \\
\hline Mean & 2.625 & 2.623 & 3.808 & 3.806 & 0.111 & 0.111 \\
\hline
\end{tabular}

Notes: TI controls = controls for altitude, whether the municipality is coastal, the number of local and national police stations. $L L M=$ Local Labor Markets. For a description of the variables, see Table A.1 Standard errors are clustered at the provincial level. *** $\mathrm{p}<0.01$, ** $\mathrm{p}<0.05$, and $* \mathrm{p}<0.1$.

\footnotetext{
${ }^{10}$ In addition to the direct perception of drivers of the level of law enforcement, parking violations might have indirect effects on the number of accidents. They include not only the fines for not paying for parking but also those for parking in places not allowed, which can complicate regular vehicular circulation.
} 
Figure 3: Municipal budget items related to road safety and recording authority

(a) Lombardy\&Veneto

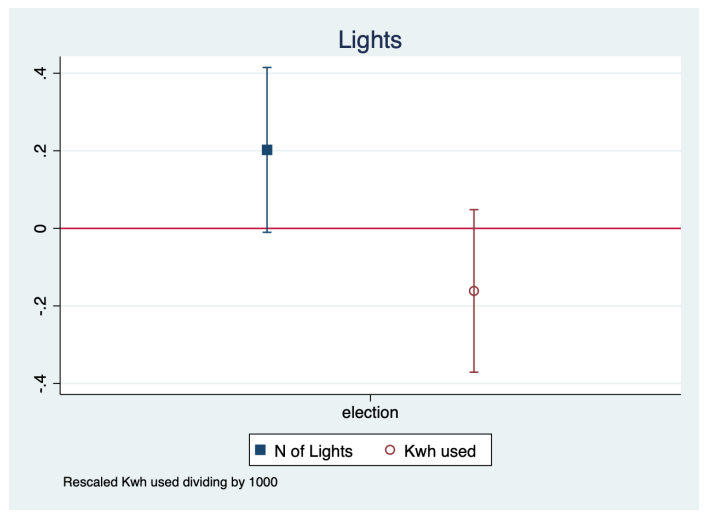

(c) Lombardy\&Veneto

Tickets

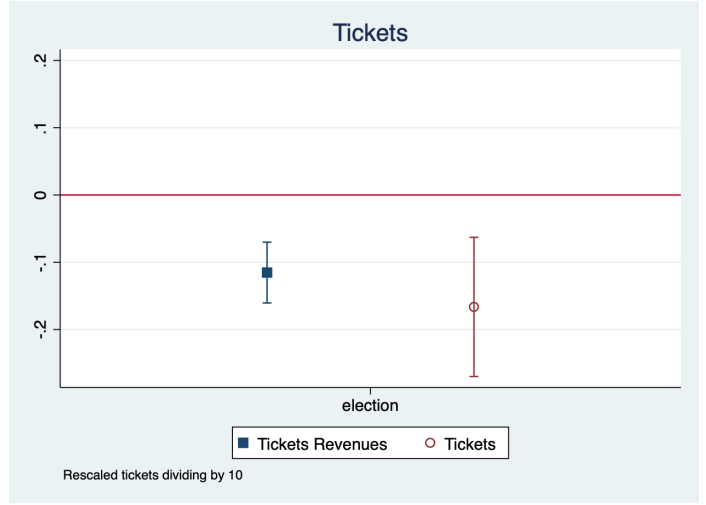

(b) Lombardy\&Veneto

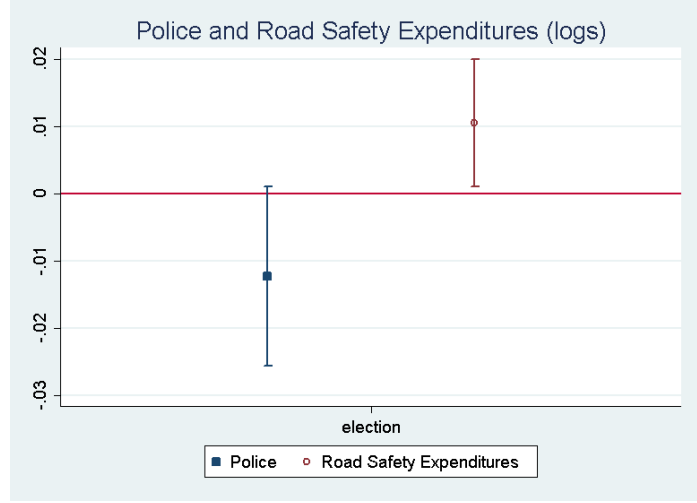

(d) Lombardy only

Authority Recording the Accident

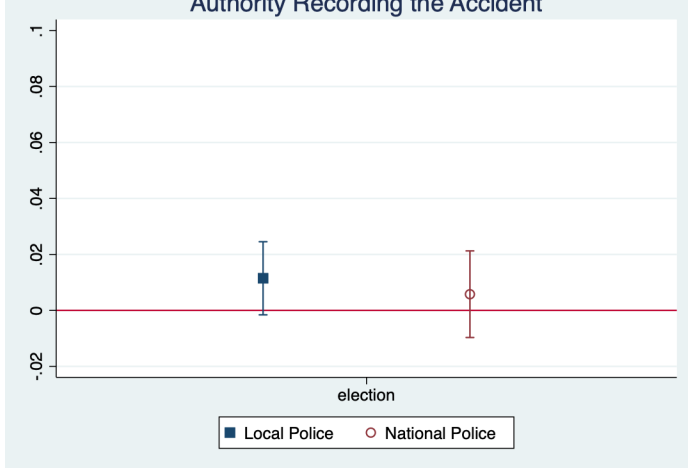

Notes: The plotted coefficients refer to the election year. For a description of the variables, see Table A.1 Coefficients plotted at $90 \%$ confidence intervals.

\subsection{Robustness Checks}

In Table 2 we reproduce the results of Panel (A) Table 1 adding a local labor market time trend 11 This is a first robustness test since the $L L M$ trends capture trends in the business cycle, which can affect the local labor market 12 Trends in road traffic accidents are connected to both the business cycle (Miller et al. 2009; Bertoli et al. 2018; Giulietti et al., 2018) and changes in tax bundles (Parry, 2004). For example, during periods of economic expansion, more individuals commute to work, people tend to take more leisure trips, and more commercial activity occurs on the road (Burgard et al., 2013; Ruhm 2000). Hence, people could be involved in more accidents simply because they drive more (Romem and Shurtz, 2016). This process would suggest an alternative mechanism to the one we propose. Results in Table 2 show that the effect on accident $(+1.4 \%)$ and injury rates $(+1.9 \%)$ is robust to our proxy for the business cycle.

As a second robustness test, since we are dealing with road traffic accidents, we control for the impact of factors common to neighboring municipalities and correlated across space for which we cannot directly control in Equation 1. such as congestion or traffic spillovers ${ }^{13}$ To account for this further dimension,

\footnotetext{
${ }^{11}$ Using provincial trends yields the same results.

${ }^{12}$ Municipal elections are credibly exogenous to economic conditions since their timing is not at the discretion of politicians.

${ }^{13}$ The existence of spatial dependence is confirmed by Moran diagnostics. All spatial diagnostics are available upon request.
} 
Table 2: Road traffic accidents: baseline results with trends

\begin{tabular}{|c|c|c|c|c|c|c|}
\hline & \multicolumn{2}{|c|}{$\begin{array}{c}\text { Accident } \\
\text { rate }\end{array}$} & \multicolumn{2}{|c|}{$\begin{array}{c}\text { Injury } \\
\text { rate }\end{array}$} & \multicolumn{2}{|c|}{$\begin{array}{c}\text { Fatality } \\
\text { rate }\end{array}$} \\
\hline & $\begin{array}{c}\text { Provicial } \\
\text { trend }\end{array}$ & $\begin{array}{l}\text { LLM } \\
\text { trend }\end{array}$ & $\begin{array}{l}\text { Provicial } \\
\text { trend }\end{array}$ & $\begin{array}{l}\text { LLM } \\
\text { trend }\end{array}$ & $\begin{array}{c}\text { Provicial } \\
\text { trend }\end{array}$ & $\begin{array}{l}\text { LLM } \\
\text { trend }\end{array}$ \\
\hline Election Year & $\begin{array}{l}0.038^{*} \\
(0.020)\end{array}$ & $\begin{array}{c}0.037^{* *} \\
(0.018)\end{array}$ & $\begin{array}{c}0.072^{* *} \\
(0.031)\end{array}$ & $\begin{array}{c}0.071^{* *} \\
(0.031)\end{array}$ & $\begin{array}{c}0.004 \\
(0.003)\end{array}$ & $\begin{array}{c}0.005 \\
(0.003)\end{array}$ \\
\hline Pop Density & Yes & Yes & Yes & Yes & Yes & Yes \\
\hline Year FE & Yes & Yes & Yes & Yes & Yes & Yes \\
\hline Municipality FE & Yes & Yes & Yes & Yes & Yes & Yes \\
\hline Observations & 31,916 & 31,909 & 31,916 & 31,909 & 31,916 & 31,909 \\
\hline Mean & 2.625 & 2.623 & 3.808 & 3.806 & 0.111 & 0.111 \\
\hline
\end{tabular}

Notes: $L L M$ stands for Local Labor Markets. Standard errors are clustered at the provincial level. *** $\mathrm{p}<0.01, * * \mathrm{p}<0.05$, and $* \mathrm{p}<0.1$.

we modify Equation 1 into the following spatial error model (SEM):

$$
\begin{gathered}
\text { Outcome }_{m t}=\beta \text { Election year }+\rho_{m}+\gamma_{t}+\pi p o p \_d e n s i t y m t+\nu_{p t} \\
\nu_{p t}=\lambda W \nu_{p t}+\epsilon_{p t}
\end{gathered}
$$

where $\nu_{p t}$ reflects the spatially autocorrelated error term and $\lambda$ identifies the spatial autocorrelation coefficient of the error term. $W$ denotes the spatial matrix for the idiosyncratic error component, and it has been specified as a contiguity-based matrix in which neighbors must share a common border ${ }^{14}$ As is apparent from Table 3 , the sign and magnitude of the effect of an election year are confirmed, and $\lambda$ is always positive and statistically significant for both accident and injury rates, which confirms the existence of unobserved factors correlated across space affecting the outcomes of neighboring municipalities $\sqrt{15}$

Table 3: Road traffic accidents: results controlling for spatial dependence in the error term

\begin{tabular}{lccc}
\hline \hline & Accident rate & Injury rate & Fatality rate \\
\hline \hline Election Year & $\begin{array}{c}0.036^{* *} \\
(0.016)\end{array}$ & $\begin{array}{c}0.066^{* *} \\
(0.028)\end{array}$ & $\begin{array}{c}0.002 \\
(0.003)\end{array}$ \\
& & & $0.652^{* * *}$ \\
$\lambda$ & $0.795^{* * *}$ & Yes & $0.089^{* *}$ \\
\hline Pop Density & Yes & Yes & Yes \\
Year FE & Yes & Yes & Yes \\
Municipality FE & Yes & & \\
Observations & 28,628 & 28,628 & 28,628 \\
Mean & 2.589 & 3.751 & 0.102 \\
\hline \hline
\end{tabular}

Notes: $\lambda$ identifies the spatial autocorrelation coefficient of the error term. For a description of the variables, see Table A.1 Standard errors are clustered at the provincial level. $* * * \mathrm{p}<0.01, * * \mathrm{p}<0.05$, and $* \mathrm{p}<0.1$

\footnotetext{
${ }^{14}$ We also apply alternative specifications of the spatial matrix as a matrix based on geographic distance and a contiguity matrix considering a queen contiguity (i.e., both common borders and vertices of the polygons are considered to define the neighbor relation). Results are robust and available upon request.

${ }^{15}$ Since spatial models require balanced panel data, the SEM model is run on the subsample of municipalities for which we have information for every year during the period of 2000-2016. Before 2000, no available accident data were available for Lombardy; thus, a balanced panel dataset for the entire observation period (1995-2016) is impossible to attain.
} 


\subsection{Composition Effects}

According to the National Institute of Statistics (ACI-ISTAT, 2013), accident severity in the country is higher at night, largely because of greater infringement of speed limits. During weekend nights, fewer but more severe accidents occur: $43 \%$ of nighttime accidents occur on Friday and Saturday nights, when the fatality rate is approximately $42 \%$ (ACI-ISTAT, 2010). In Figure A.5, we plot the values for fatality rates and the lesivity rates (i.e., total deaths plus total injuries out of accidents) per type of accidents in our sample, and they confirm the evidence at the national level. These figures are also in line with the general trends at the European level, where the most severe accidents occur during weekends and on rural roads (European Road Safety Observatory, 2017). Hence, we investigate whether the composition of accidents experiences a political cycle: certain types of traffic violations might have a worse impact on the severity and frequency of accidents. We have only scant information on the types of tickets and the ways their composition changes, but we have data on accident types.

We estimate Equation 1 using the accident, injury, and fatality rates differentiated by 5 categories as outcomes: rush hour accidents, daytime and nighttime accidents, accidents on weekends, and accidents that occurred under good weather conditions. Additionally, we compare accidents on urban and rural roads. These checks are possible only at the yearly level, as the information on the type of accidents is not provided at a more disaggregated level. The estimated coefficients, plotted in Figure 4 confirm our intuition, as the election year has no statistically significant effect on the accident rate during nights and weekends, indicating the most severe accidents do not increase as a result of the political cycle. The rural accident rate does not significantly change, accidents during rush hours increase, as do the injury rate records of daytime and good weather events. 
Figure 4: Results per type of accident

(a)

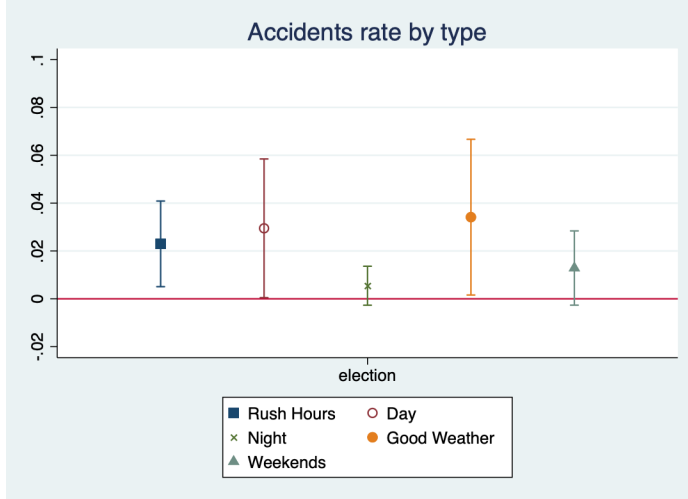

(c)

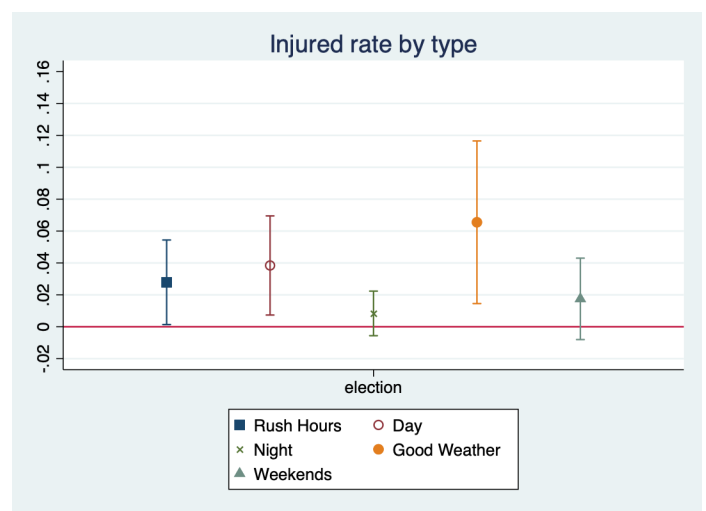

(e)

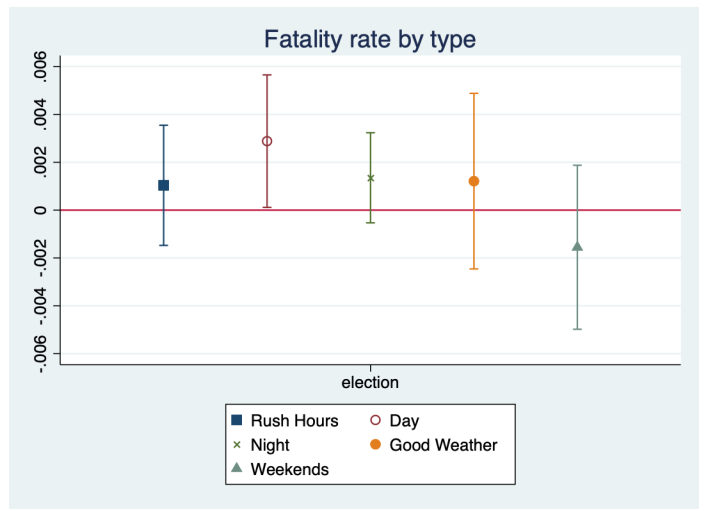

(b)

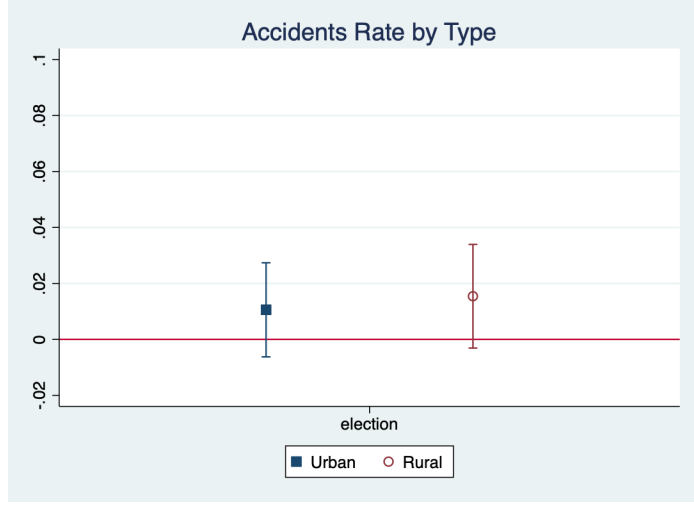

(d)

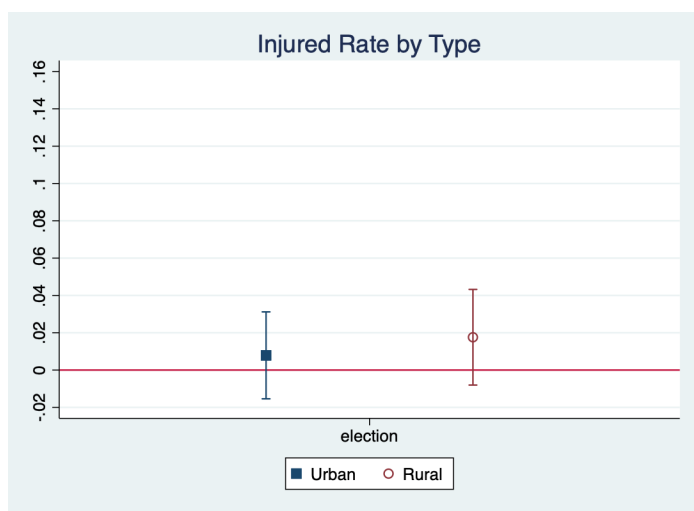

(f)

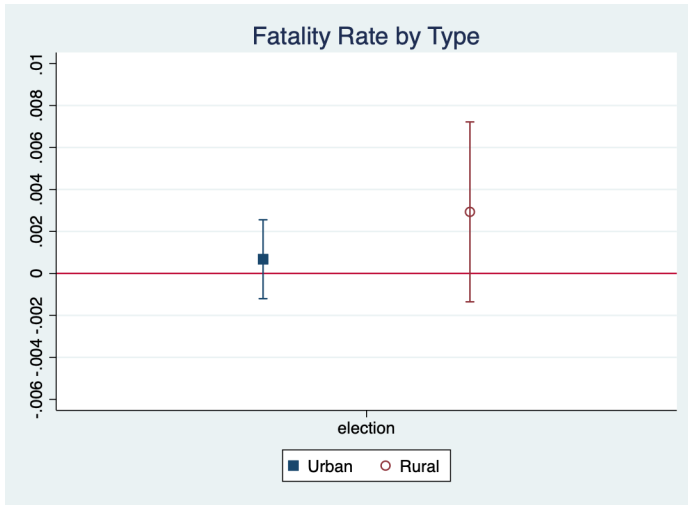

Notes: The plotted coefficients refer to the election year. For a description of the variables, see Table A.1 Coefficients plotted at $90 \%$ confidence intervals.

\subsection{Alternative Measures of the Political Cycle}

We check whether our results are driven mainly by the way in which we define the political cycle, exploiting alternative specifications to capture it. First, following Foremny and Riedel (2014), rather than considering only the election year, we add dummies for the year before and the year after an 
election ${ }^{16}$ The significance and direction of the effect due to the election year is confirmed, as shown in Table 4, as well as its magnitude. The effect of the election year is a $1.6 \%$ increase in the accident rate (Column 2) and a $2 \%$ increase in the injury rate (Column 4). No effect is detected on the fatality rate.

Next, we consider a leads and lags transformation of Equation 1, in which we control for the yearly distance from the election year (i.e., election year=distance zero) to estimate the impact of the political cycle. We plot the estimated coefficients of this model in Figures 5, 6, and 7. We complement the plots by also presenting the results for the estimated coefficients on Ticket revenues to provide a better idea of the opposite trend. The baseline results are confirmed independently from the selection of the reference year.

Table 4: Road traffic accidents: results around the election year

\begin{tabular}{|c|c|c|c|c|c|c|}
\hline & \multicolumn{2}{|c|}{$\begin{array}{c}\text { Accident } \\
\text { rate }\end{array}$} & \multicolumn{2}{|c|}{$\begin{array}{c}\text { Injury } \\
\text { rate }\end{array}$} & \multicolumn{2}{|c|}{$\begin{array}{c}\text { Fatality } \\
\text { rate }\end{array}$} \\
\hline & $(1)$ & $(2)$ & $(3)$ & (4) & $(5)$ & $(6)$ \\
\hline Before & $\begin{array}{c}0.006 \\
(0.020)\end{array}$ & $\begin{array}{c}0.006 \\
(0.020)\end{array}$ & $\begin{array}{c}0.000 \\
(0.031)\end{array}$ & $\begin{array}{c}0.000 \\
(0.031)\end{array}$ & $\begin{array}{c}-0.006 \\
(0.004)\end{array}$ & $\begin{array}{l}-0.006 \\
(0.004)\end{array}$ \\
\hline Election Tear & $\begin{array}{l}0.043^{*} \\
(0.020)\end{array}$ & $\begin{array}{l}0.042^{*} \\
(0.021)\end{array}$ & $\begin{array}{c}0.075^{* *} \\
(0.031)\end{array}$ & $\begin{array}{c}0.075^{* *} \\
(0.031)\end{array}$ & $\begin{array}{c}0.002 \\
(0.003)\end{array}$ & $\begin{array}{c}0.002 \\
(0.003)\end{array}$ \\
\hline After & $\begin{array}{c}0.008 \\
(0.016) \\
\end{array}$ & $\begin{array}{c}0.007 \\
(0.017) \\
\end{array}$ & $\begin{array}{c}-0.002 \\
(0.026) \\
\end{array}$ & $\begin{array}{l}-0.002 \\
(0.027) \\
\end{array}$ & $\begin{array}{l}-0.006 \\
(0.004) \\
\end{array}$ & $\begin{array}{l}-0.006 \\
(0.004) \\
\end{array}$ \\
\hline Pop Density & No & Yes & No & Yes & No & Yes s \\
\hline Year FE & Yes & Yes & Yes & Yes & Yes & Yes \\
\hline Municipal FE & Yes & Yes & Yes & Yes & Yes & Yes \\
\hline Observations & 31,916 & 31,909 & 31,916 & 31,909 & 31,916 & 31,909 \\
\hline Mean & 2.623 & 2.625 & 3.806 & 3.808 & 0.111 & 0.111 \\
\hline
\end{tabular}

Notes: Before is equal to 1 for the year before election, while After is a dummy for the year after election. The terms are 4 years until 2001 and 5 years after 2001. Only municipalities with or above 1,000 inhabitants are included. For a description of the variables, see Table A.1 Standard errors are clustered at the provincial level. ${ }^{* *} \mathrm{p}<0.01,{ }^{*} \mathrm{p}<0.05$, and $* \mathrm{p}<0.1$.

\footnotetext{
${ }^{16}$ The reference years are the second year after the election before the 5 -year term was instituted, and years +2 and +3 from the election after the introduction of the 5-year term.
} 
Figure 5: Political cycle over the accident rates

(a) Reference year: +2

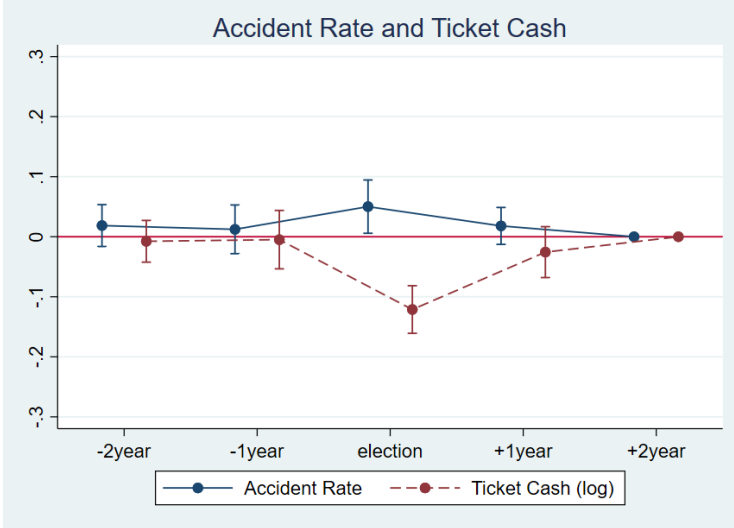

(c) Reference year: -2

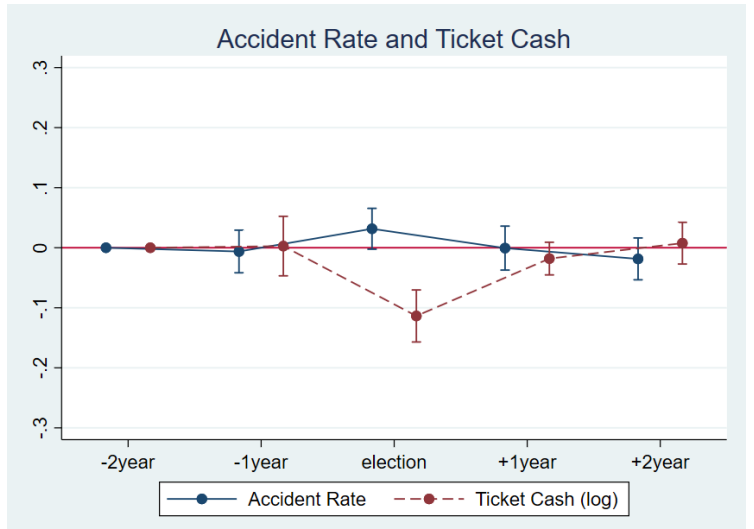

(b) Reference year: +1

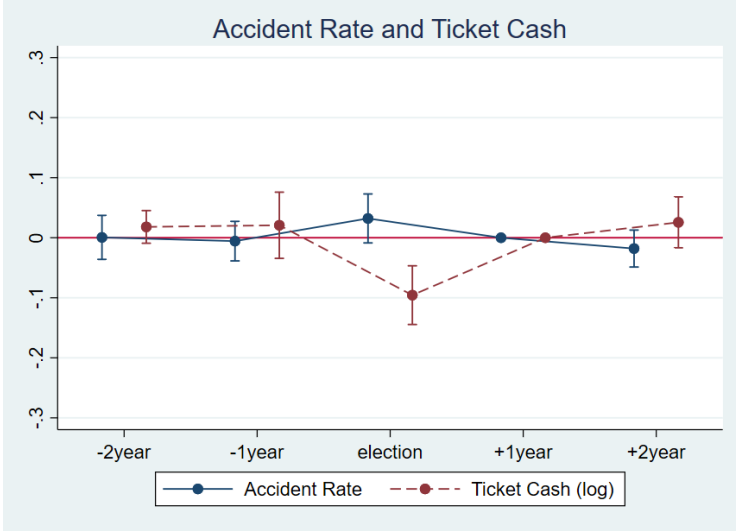

(d) Reference year: -1

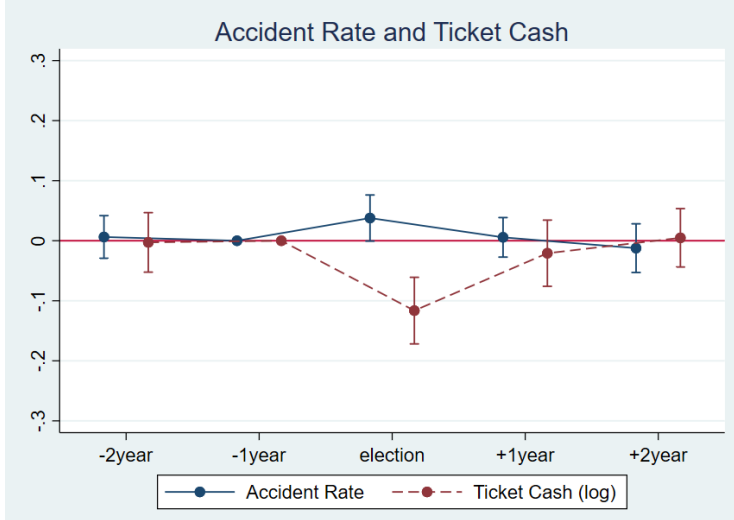

Notes: The reference years are calculated as the distance from the mayoral election year. For a description of the variables, see Table A.1 Coefficients plotted at $90 \%$ confidence intervals. 
Figure 6: Political cycle over the injury rates

(a) Reference year: +2

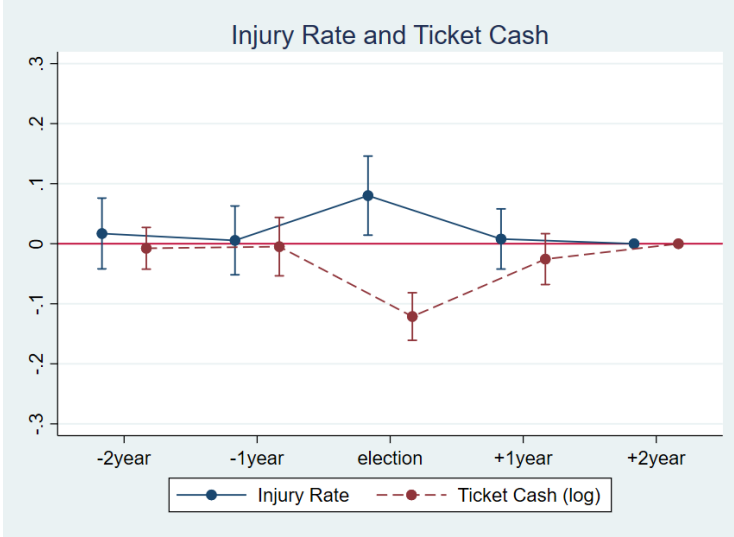

(c) Reference year: -2

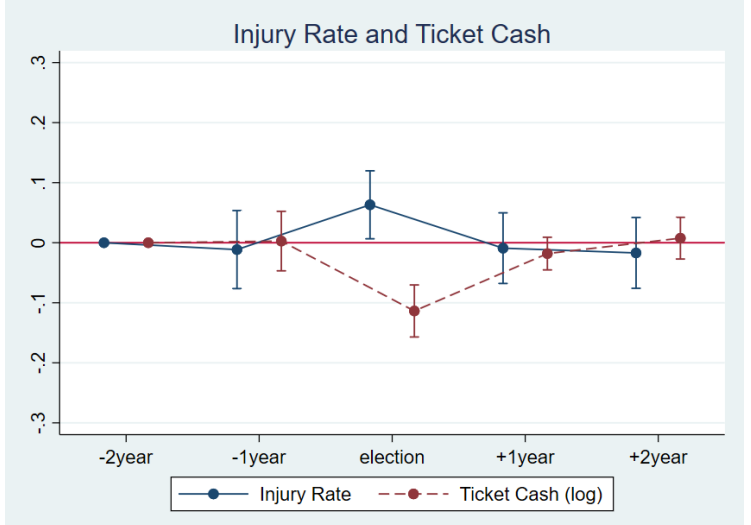

(b) Reference year: +1

Injury Rate and Ticket Cash

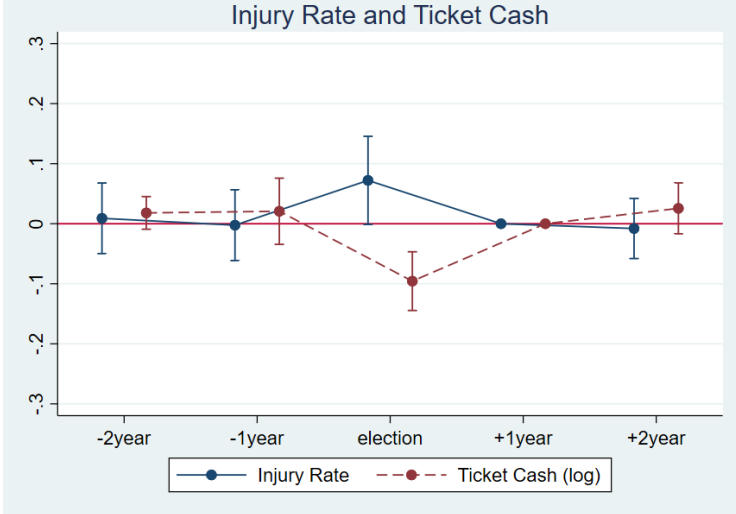

(d) Reference year: -1

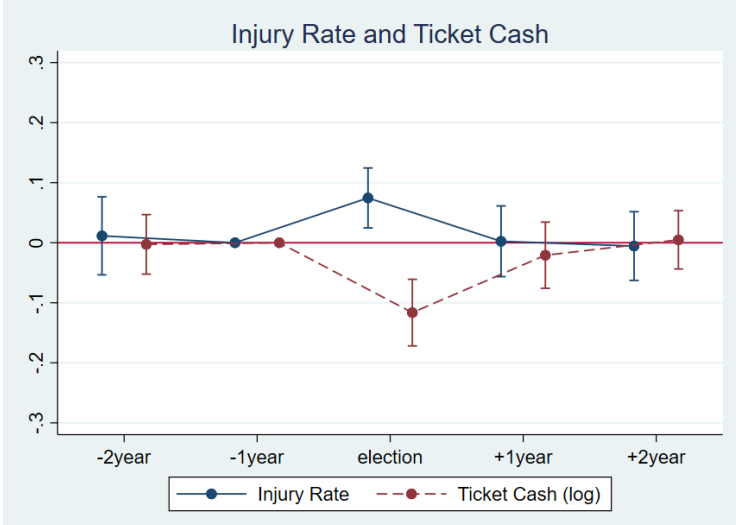

Notes: The reference years are calculated as the distance from the mayoral election year. For a description of the variables, see Table A.1 Coefficients plotted at $90 \%$ confidence intervals. 
Figure 7: Political cycle over the fatality rate

(a) Reference year: +2

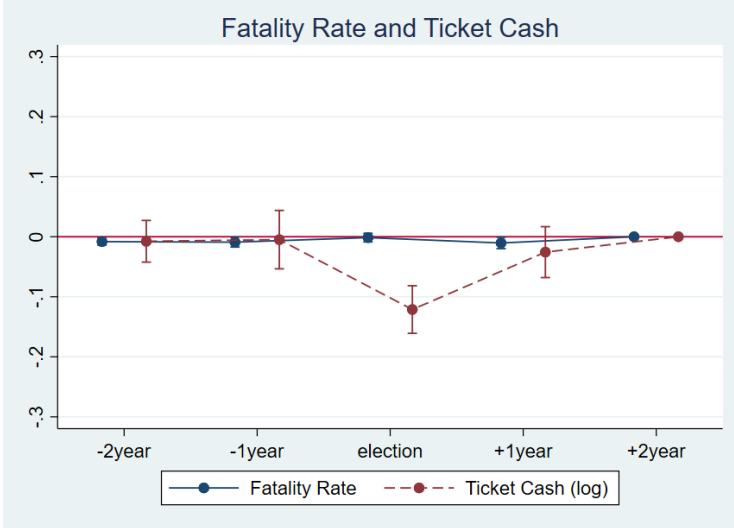

(c) Reference year: -2

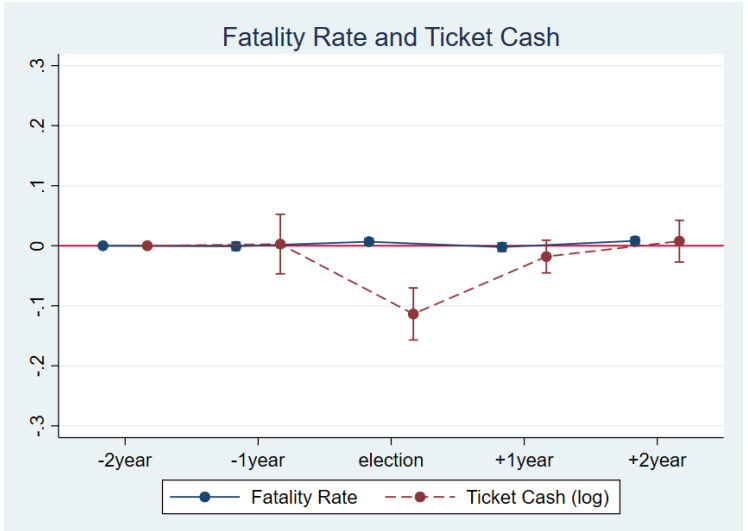

(b) Reference year: +1

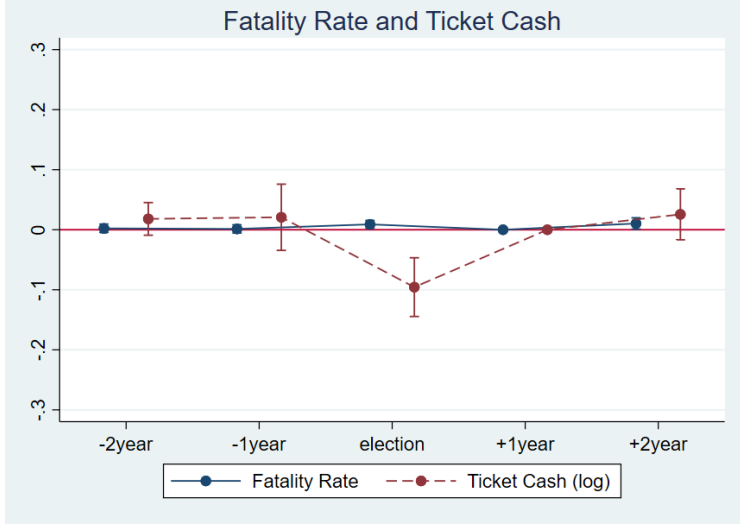

(d) Reference year: -1

Fatality Rate and Ticket Cash

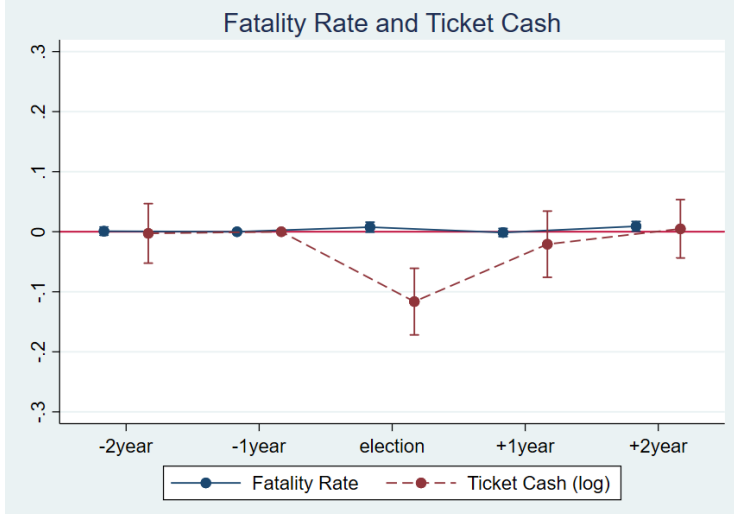

Notes: The reference years are calculated as the distance from the mayoral election year. For a description of the variables, see Table A.1 Coefficients plotted at $90 \%$ confidence intervals. 


\subsection{During the Election Year}

Voters' memories are commonly expected to be short term; thus, the need to secure political consensus should be stronger in proximity to the election date. We test this expectation by applying the model in Equation 5 to quarterly rates of accidents, injuries, and fatalities ${ }^{17}$ We define quarter 0 as the election quarter, and we retain all the observations from three quarters before the election quarter $(9 / 11$ months before the election date) to the two subsequent quarters (end of the election year). Considering more than 1 year before the election date would water down the effect of the political cycle. Considering six months after the election allows us to check what happens when the elected mayor takes office, since a couple of months generally pass before the new government becomes fully operational. Suppose, as is often the case, the election date is in June of year $t$ (i.e., the end of the second quarter of the election year). Our sample definition means that in this specification, we use observations from July of year $t-1$ (11 months before) until December of year $t$.

$$
\text { Outcome }_{m q}=\sum_{q=-3}^{+2} \gamma_{q} \text { Distance }_{q}+\lambda_{q}+\rho_{m}+\gamma_{t}+\pi \text { pop_density } m t+\epsilon_{p}
$$

The results for the quarters specification are shown in Table 5 , where we also include quarterly fixed effects $\left(\lambda_{q}\right)$ in addition to the usual controls and fixed effects. The results show the increases in both accident and injury rates are entirely driven by the two quarters before the electoral one and, interestingly, by the second quarter of the mayoral term. During the election quarter, we observe a negative effect on both accident and injury rates, although the effect is significant only on the accident rate. These findings shed new light on the timing of the political cycle. The need to please the constituency strikes twice during the cycle: just before the election and at the very beginning of the mayoral term. During the weeks surrounding the election date, fewer accidents are better.

Results of Table 5 stem from a sample in which we maintain only the quarters around the election quarter. Since $97 \%$ of the time the election quarter is April-June (Table 6), the effect we see may be seasonal, because the quarter with the highest accident and injury rates is July-September (see Figure A.6 and Table A.4. To address this concern, we estimate Equation 5 on year $+2(-3)$ and year $+3(-2)$ from the true election year. The results of these placebo tests are reported in Table 7 . We do not assess any effect of the quarters before and after the fake election quarter.

\footnotetext{
${ }^{17}$ We cannot repeat this analysis at the quarterly level for the budget items because data on budget items are available only at the yearly level.
} 
Table 5: Road traffic accidents: quarterly results

\begin{tabular}{lccc}
\hline \hline & $\begin{array}{c}\text { Accident } \\
\text { rate }\end{array}$ & $\begin{array}{c}\text { Injury } \\
\text { rate }\end{array}$ & $\begin{array}{c}\text { Fatality } \\
\text { rate }\end{array}$ \\
\hline \hline & $(1)$ & $(2)$ & $(3)$ \\
Quarter -2 & $0.041^{*}$ & $0.078^{*}$ & -0.002 \\
& $(0.022)$ & $(0.044)$ & $(0.004)$ \\
Quarter -1 & $0.088^{* *}$ & $0.155^{* *}$ & 0.001 \\
& $(0.039)$ & $(0.062)$ & $(0.004)$ \\
Quarter 0 & -0.022 & 0.018 & 0.002 \\
& $(0.022)$ & $(0.043)$ & $(0.003)$ \\
Quarter 1 & -0.008 & -0.007 & 0.000 \\
& $(0.012)$ & $(0.021)$ & $(0.003)$ \\
Quarter 2 & $0.053^{* *}$ & $0.103^{* *}$ & 0.000 \\
& $(0.022)$ & $(0.045)$ & $(0.004)$ \\
\hline & & & \\
Year FE & Yes & Yes & Yes \\
Municipal FE & Yes & Yes & Yes \\
Quarter FE & Yes & Yes & Yes \\
Observations & 38,701 & 38,701 & 38,701 \\
Mean & 0.653 & 0.945 & 0.029 \\
\hline \hline
\end{tabular}

Notes: The reference quarter is Quarter -3 , which means 9 months before the election quarter. For a description of the variables, see Table A.1 Standard errors are clustered at the provincial level. *** $\mathrm{p}<0.01,{ }^{* *} \mathrm{p}<0.05$, and $* \mathrm{p}<0.1$.

Table 6: Distribution of election quarters

\begin{tabular}{lcc}
\hline \hline Election quarter & Entire sample (\%) & Sample above 1,000 (\%) \\
\hline \hline Jan-Mar & 1.12 & 1.20 \\
Apr-Jun & 97.42 & 97.16 \\
Jul-Sep & 0.03 & 0.03 \\
Oct-Dec & 1.43 & 1.61 \\
\hline \hline
\end{tabular}


Table 7: Placebos: Election quarter in a non election year

\begin{tabular}{|c|c|c|c|}
\hline & $\begin{array}{c}\text { Accident } \\
\text { rate }\end{array}$ & $\begin{array}{c}\text { Injury } \\
\text { rate }\end{array}$ & $\begin{array}{c}\text { Fatality } \\
\text { rate }\end{array}$ \\
\hline & $(1)$ & $(2)$ & $(3)$ \\
\hline \multicolumn{4}{|c|}{ PANEL A: } \\
\hline \multicolumn{4}{|c|}{ Election quarter in year +2 from real elections } \\
\hline \multirow[t]{2}{*}{ Quarter -2} & 0.051 & 0.064 & -0.005 \\
\hline & $(0.033)$ & $(0.053)$ & $(0.005)$ \\
\hline \multirow[t]{2}{*}{ Quarter -1 } & 0.047 & 0.054 & -0.004 \\
\hline & $(0.035)$ & $(0.055)$ & $(0.005)$ \\
\hline \multirow[t]{2}{*}{ Quarter 0} & -0.003 & -0.01 & 0.002 \\
\hline & $(0.017)$ & $(0.034)$ & $(0.006)$ \\
\hline \multirow[t]{2}{*}{ Quarter 1} & -0.002 & 0.001 & 0.002 \\
\hline & $(0.012)$ & $(0.019)$ & $(0.003)$ \\
\hline \multirow[t]{2}{*}{ Quarter 2} & 0.049 & 0.062 & 0.001 \\
\hline & $(0.035)$ & $(0.058)$ & $(0.004)$ \\
\hline Mean & 0.656 & 0.954 & 0.029 \\
\hline Observations & 42,810 & 42,810 & 42,810 \\
\hline
\end{tabular}

PANEL B:

Election quarter in year +3 from real elections

Quarter - 2

(0.034) $\quad(0.05) \quad(0.004)$

Quarter $-1 \quad 0.067 \quad 0.086 \quad-0.004$

Quarter $0 \quad(0.039) \quad(0.06) \quad(0.004)$

$\begin{array}{ccc}0.024 & 0.004 & 0.006 \\ (0.02) & (0.035) & (0.005)\end{array}$

$\begin{array}{llll}\text { Quarter } 1 & 0.006 & 0.004 & -0.002\end{array}$

$\begin{array}{lll}(0.012) & (0.022) \quad(0.003)\end{array}$

$\begin{array}{llll}\text { Quarter } 2 & 0.05 & 0.055 & -0.002\end{array}$

$(0.034) \quad(0.047) \quad(0.004)$

Mean $\quad 36,441 \quad 36,441 \quad 36,441$

$\begin{array}{llll}\text { Observations } & 0.67 & 0.973 & 0.03\end{array}$

\begin{tabular}{lccc}
\hline & & & \\
Year FE & Yes & Yes & Yes \\
Municipal FE & Yes & Yes & Yes \\
Quarter FE & Yes & Yes & Yes \\
\hline \hline
\end{tabular}

Notes: The reference quarter is Quarter -3 , which means 9 months before the election quarter. Standard errors are clustered at the provincial level. $* * * \mathrm{p}<0.01, * * \mathrm{p}<0.05$, and $* \mathrm{p}<0.1$. 


\subsection{Spillover Effects}

Even though the effects of the municipal election year are robust, this result may, in part, be the result of spillover effects due to other political cycles, such as those due to national elections or elections taking place in neighboring municipalities.

We first assess the impact, if any, of national elections. National elections overlap municipal elections for $11 \%$ of the elections in our sample. The importance of the national level is twofold: Italian municipalities often rely on the financial support of the central state, and a national police force is well spread locally and can intervene in matters of road safety. Based on the 5 national election years in our sample (1996, 2001, 2006, 2008, and 2013), we use Equation 1 to estimate the election year effect, and we report the results in Table 8 . The direction of a national election year is negative and significant: a lower accident rate, a lower injury rate, and a lower fatality rate. However, these results are not robust to the use of provincial fixed effects, but they are for the effect on the fatality rate (see Table B.3.

In the national election year, ticket revenues increase but not ticket rates, as apparent from Part (c) of Figure 8. Both road safety expenditures (Part (b)) and light consumption increase (Part (a)). We link the increase in ticket revenues to a composition effect as described by the evidence in Table A.3 tickets for Serious violations of road safety regulations increase, as does the activity level of local police. The result on road safety expenditures relates these kinds of interventions to electoral years, and it rules out the possibility that road maintenance causes the increase in accidents when a local election is held. Overall, when municipal and national elections occur in the same year, the observed effects of local elections represent a lower bound of the true ones.

Since elections are staggered, two types of possible spillovers can occur from elections in neighboring municipalities: (1) spillovers in municipality $\mathrm{X}$ when no elections occur in municipality $\mathrm{X}$ but elections occur in the neighboring municipality $\mathrm{Z}$ and (2) spillovers in municipality $\mathrm{X}$ when elections occur in both municipality $\mathrm{X}$ and the neighboring municipality $\mathrm{Z}$. We test these scenarios by estimating the following model:

Outcome $_{m t}=\beta$ Election year $+\alpha$ Neighboring election year $+\lambda$ Interaction $+\rho_{m}+\gamma_{t}+\pi p o p_{-} d e n s i t y_{m t}+\epsilon_{p}$

$\beta$ captures the effect of an election in municipality $m$ when no elections occur in neighboring municipalities, while $\beta+\lambda$ captures the effect of an election in municipality $m$ when elections occur in neighboring municipalities. As shown in Table 9, the main effect of the electoral year does not change whenever neighboring municipalities hold elections. 
Figure 8: Municipal budget items related to road safety with national election

(a) Lombardy\&Veneto

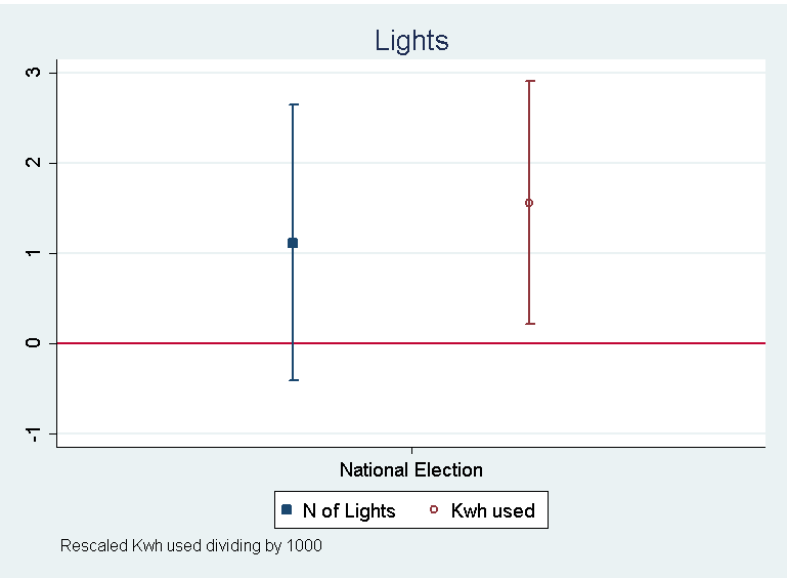

(b) Lombardy\&Veneto

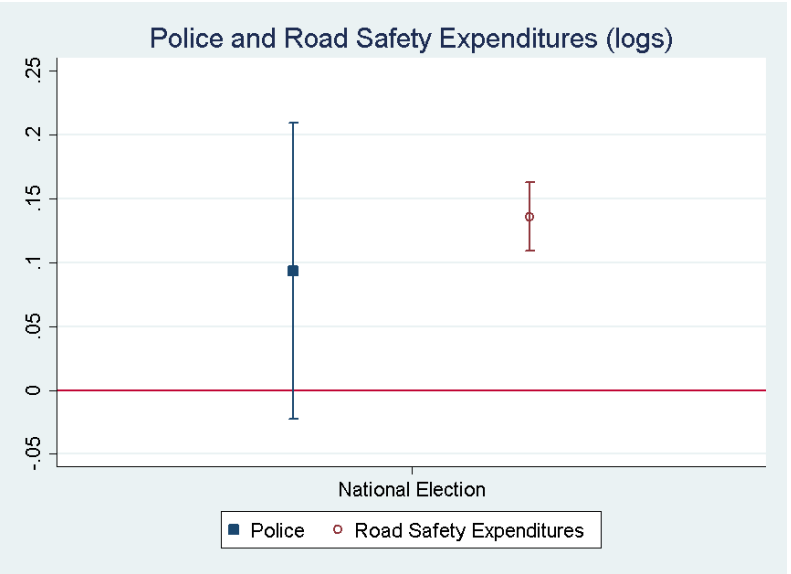

(c) Lombardy\&Veneto

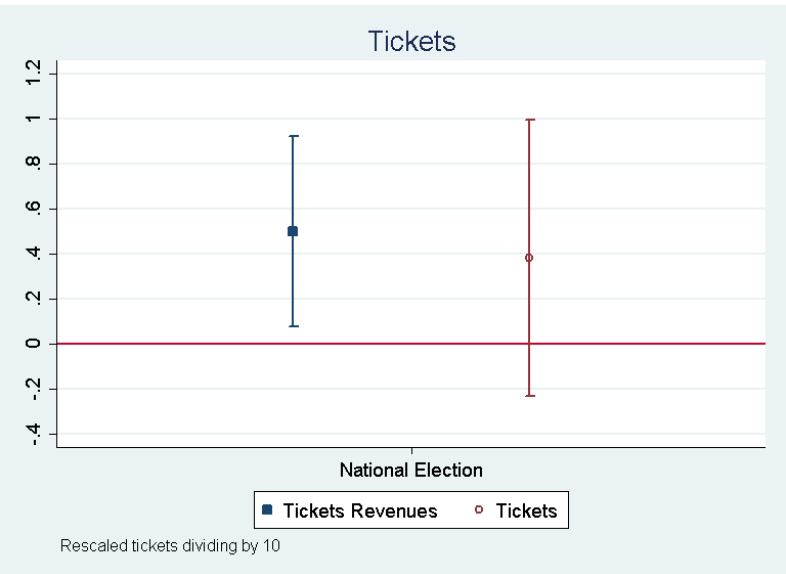

Notes: The plotted coefficients refer to a national election year. For a description of the variables, see Table A.1 Coefficients plotted at $90 \%$ confidence intervals. 
Table 8: Road traffic accidents over the national election cycle

\begin{tabular}{lccc}
\hline \hline & Accident rate & Injury rate & Fatality rate \\
\hline \hline & $(1)$ & $(2)$ & $(2)$ \\
Election Year & $-0.840^{* * *}$ & $-1.157^{* * *}$ & $-0.168^{* * *}$ \\
& $(0.152)$ & $(0.201)$ & $(0.018)$ \\
\hline \multirow{2}{*}{ Pop Density } & Yes & Yes & Yes \\
Year FE & Yes & Yes & Yes \\
Municipal FE & Yes & Yes & Yes \\
& & & \\
Observations & 31,883 & 31,883 & 31,883 \\
Mean & 2.625 & 3.810 & 0.111 \\
\hline \hline
\end{tabular}

Notes: For a description of the variables, see Table A.1 The national elections considered took place in 1996, 2001, 2006, 2008, and 2013. Standard errors are clustered at the provincial level. *** $\mathrm{p}<0.01, * * \mathrm{p}<0.05$, and $* \mathrm{p}<0.1$.

Table 9: Road traffic accidents: results controlling for elections in neighboring municipalities

\begin{tabular}{lcccccc}
\hline \hline & \multicolumn{2}{c}{$\begin{array}{c}\text { Accident } \\
\text { rate }\end{array}$} & \multicolumn{2}{c}{$\begin{array}{c}\text { Injury } \\
\text { rate }\end{array}$} & \multicolumn{2}{c}{$\begin{array}{c}\text { Fatality } \\
\text { rate }\end{array}$} \\
\hline \hline & $(1)$ & $(2)$ & $(3)$ & $(4)$ & $(5)$ & $(6)$ \\
\hline Election Year & & & & & & \\
& $0.041^{* *}$ & $0.059^{* * *}$ & $0.075^{* *}$ & $0.097^{* *}$ & 0.004 & -0.002 \\
& $(0.019)$ & $(0.020)$ & $(0.030)$ & $(0.037)$ & $(0.003)$ & $(0.001)$ \\
Neighbors Election & 0.003 & 0.007 & 0.008 & 0.013 & 0.002 & 0.001 \\
& $(0.006)$ & $(0.006)$ & $(0.010)$ & $(0.009)$ & $(0.001)$ & $(0.001)$ \\
Election Year* & & -0.009 & & & & \\
Neighbors Election & & $(0.009)$ & & $(0.011$ & & 0.003 \\
& & & & & & \\
Pop Density & Yes & Yes & Yes & Yes & Yes & Yes \\
Year FE & Yes & Yes & Yes & Yes & Yes & Yes \\
Municipal FE & Yes & Yes & Yes & Yes & Yes & Yes \\
& & & & & & \\
Observations & 31,896 & 31,896 & 31,896 & 31,896 & 31,896 & 31,896 \\
Mean & 2.625 & 2.625 & 3.808 & 3.808 & 0.111 & 0.111 \\
\hline \hline
\end{tabular}

Notes: Neighbors election is a dummy equal 1 if elections occur in a neighboring municipality and 0 otherwise. For a description of the variables, see Table A.1 Standard errors are clustered at the provincial level. *** $\mathrm{p}<0.01, * * \mathrm{p}<0.05$, and $* \mathrm{p}<0.1$.

\subsection{Municipality Types}

As the final step in our analysis, we focus only on the injury rate. Given the lack of an impact on fatality rates, injuries represent the stronger economic cost caused by the political cycle of road traffic accidents. Retaining the injury rate as the main outcome and Equation 1 as the baseline, we test the relevance of the interaction of the election year with 9 variables: 5 capturing the characteristics of the municipal political environment and 4 capturing municipal characteristics that might be relevant in the contexts of traffic accidents and of our mechanism. Each characteristic is tested as controlling (Panel B) or not controlling (Panel A) for the resident population.

The 5 characteristics of the political environment are 1) the presence of a runoff system, which in Italy holds for municipalities with more than 15,000 inhabitants, since it helps to select better quality politicians (Bordignon et al. 2017); 2) the number of candidates running for election, proxying for high political competition; 3) the margin of victory in the election; and 4) the term limit status of the incumbent mayor. The lack of a term limit should reflect higher engagement in the political cycle. However, this 
last measure has two drawbacks. First, over time, several exceptions have been made to the term limit rule (two terms since 1993), the last of which entered into force in 2014 for small municipalities (those with fewer than 3,000 inhabitants). Second, local politicians care about voters' support even when facing a term limit for reasons other than their immediate re-election as mayor. They may have their own candidate to support, or they may want to run for higher office, support their own political coalition, leave a positive legacy, or run again in mayoral elections in the future (Gagliarducci and Nannicini, 2013; Gamalerio, 2019). As a fifth characteristic of the political environment, we consider the level of trust that local residents have in the effectiveness of the local versus the national government. We proxy for this trust level with the electoral results of a referendum for more decentralization launched by a center-right party (i.e., Lega Nord) in 2018. This referendum was run only in Lombardy and Veneto. We consider the municipal turnout levels to be an index of trust in local institutions: turnout levels were directly related to a favorable vote for more independence from the central government. Columns from (1) to (5) of Table 10 show the results for the interactions (Difference) of these first 5 characteristics. While a more competitive political environment seems to exacerbate the impact on the injury rate, facing a term limit does not produce any significant effect in our institutional framework. Having more candidates and not having a runoff system drive the effect of the election year on the injury rate.

The other 4 characteristics proxy for municipal dimensions, for which we do not control in the main specification, but which could matter in principle. We use the number of registered vehicles per resident per municipality (available from 2002) to control for the relative importance of tickets for the residence population. This channel does not produce any significant difference. We check whether any impact is due to the adherence of municipality $m$ to a consortium of municipalities to provide public services. Municipalities outside of a consortium have, as expected, a stronger political cycle, and the difference for municipalities belonging to a consortium is statistically different from zero. Then, we calculate the distance of each municipality to the nearest national police station (with 0 being a municipality which has at least one national police station). This measure is a more appropriate way to control for the national police interventions than using a dummy for the presence of a national police station. We define far as equal to 1 when the nearest national police station is at a distance above the average distance (i.e., $4.85 \mathrm{~km}$ or 3 miles). The effect of the election year is stronger when the municipality has no national policy station in proximity. Finally, using the distribution of the resident population, we define small municipalities as those with less than 4,070 inhabitants, and we assess the heterogeneous effect driven by this dimension: higher injured rates occur only in smaller municipalities. 


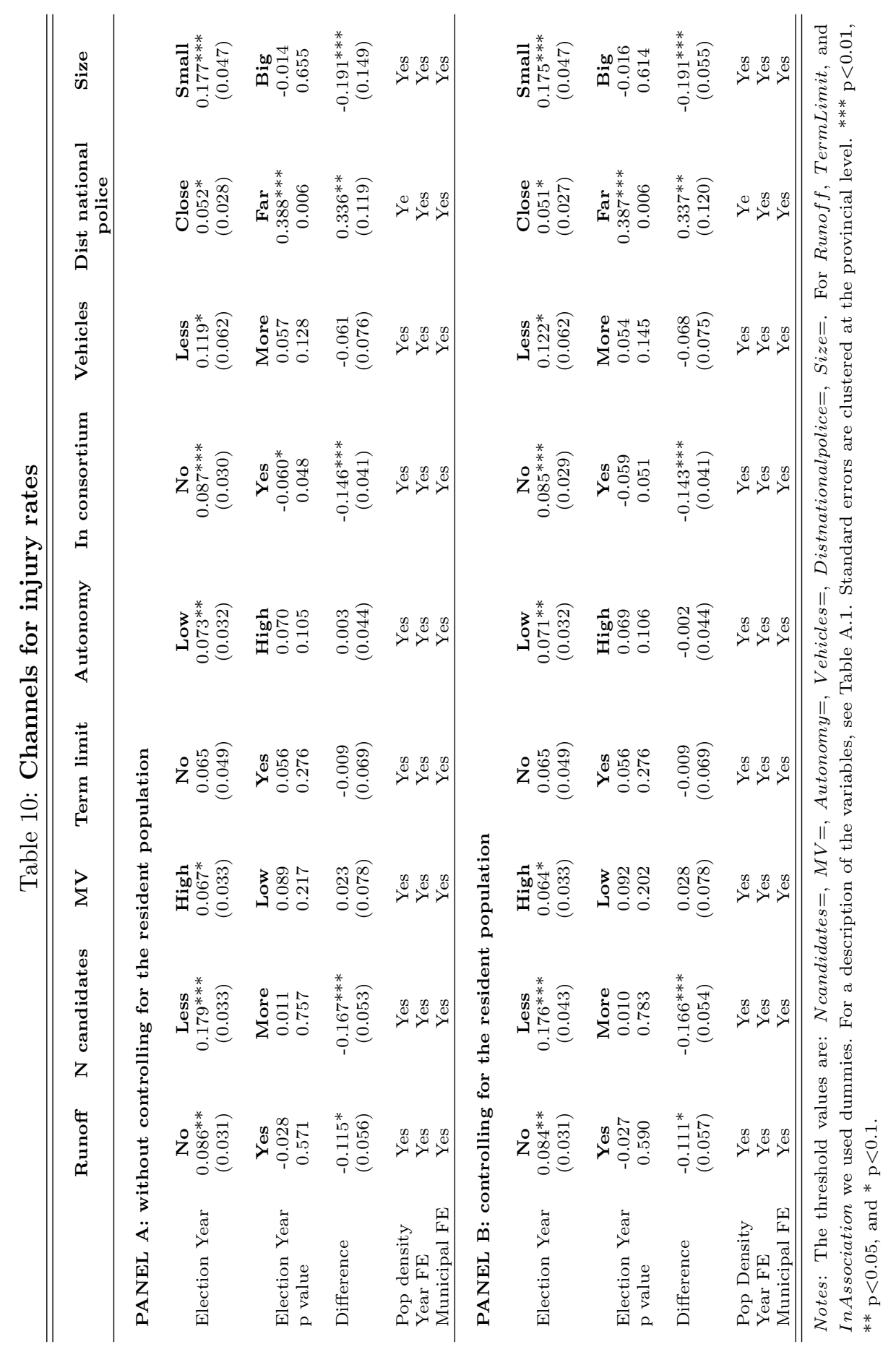




\section{Conclusion}

We assess the existence of a political cycle in road traffic accidents using data from two Italian regions, Lombardy and Veneto, which account for a quarter of Italian municipalities and population, over the period of 1995-2016. During municipal election years, we estimate a $1.5 \%$ increase in the accident rate and a $2 \%$ increase in the injury rate but find no effect on the fatality rate. Our robust effects are driven by a change in the type of enforcement of road traffic laws, as captured by a decrease in the ticket rate as well as by an increase in road safety expenditures. Our analysis also sheds light on the fact that during an election year, not only the pre-election months but also the first months of the mayoral term are critical. These results of the mayoral political cycle, during which the mayor is the head of the local police force, are generalizable to other contexts in which the main officers responsible for enforcing road traffic safety measures are subject to direct elections. As such, they raise concerns regarding the side effects of decentralizing security competences. From the analysis of the channels, closer proximity to national police stations decreases the impact of election years on adverse events, suggesting that a strong presence of higher levels of government could mitigate the costs of the political cycle for road traffic accidents. 


\section{References}

[1] ACI-ISTAT, 2010. Rapporto sugli stradali 2009. Available at http://www.aci.it/laci/ studi-e-ricerche/dati-e-statistiche/incidentalita.html.

[2] ACI-ISTAT, 2013. Incidenti Stradali in Italia. Available at http://www.aci.it/laci/ studi-e-ricerche/dati-e-statistiche/incidentalita.html.

[3] ACI-ISTAT, 2014. Incidenti Stradali in Italia. Available at http://www.istat.it/it/archivio/ 137546 .

[4] Abouk, R. and S. Adams. 2013. "Texting bans and fatal accidents on roadways: do they work? or do drivers just react to announcements of bans?" American Economic Journal Applied Economics. 5 (2): 179-199.

[5] Adams, S. and C. Cotti. 2008. "Drunk driving after the passage of smoking bans in bars." Journal of Public Economics. 92(5): 1288-1305.

[6] Akhmedov, A. and E. Zhuravskaya. 2004. "Opportunistic political cycles: test in a young democracy setting." The Quarterly Journal of Economics 119(4): 1301-1338.

[7] Albalate, D. and A. Yarygina. 2017. "Road Safety Determinants: Do Political Institutions Matter?" International Journal Of Transport Economics. 44(2): 315-348.

[8] Alesina, A. and M. Paradisi, 2017. "Political budget cycles: Evidence from Italian cities." Economics E Politics 29(2):57-177.

[9] Anbarci, N., Escaleras, M. and C. Register. 2006. "Traffic Fatalities and Public Sector Corruption." Kyklos. 59(3): 327-344.

[10] Ashenfelter, O., 2006. "Measuring The Value Of A Statistical Life: Problems And Prospects." Economic Journal. 116(510): C10-C23.

[11] Baskaran, T, Min, B., and Y. Uppal, 2015. "Election cycles and electricity provision: Evidence from a a quasi-experiment with Indian special elections." Journal of Public Economics. 126: 64-73.

[12] Bee, A. C. and S. R. Moulton. 2015. "Political budget cycles in U.S. municipalities." Economics of Governance. 16(4): 379-403.

[13] Bertoli, P., Grembi, V. and J. Vall-Castello. 2018. "Not All Silver Lining? The Great Recession and Road Traffic Accidents." Regional Science and Urban Economics. 70: 274-288.

[14] Bertrand, M., Djankov, S., Hanna, R. and S. Mullainathan. 2007. "Obtaining a Driver's License in India: An Experimental Approach to Studying Corruption." Quarterly Journal Of Economics. 122(4): 1639-1676.

[15] Besley, T. and I. Preston. 2007. "Electoral Bias and Policy Choice: Theory and Evidence". Quarterly Journal of Economics. 122(4): 1473-1510.

[16] Blincoe,L. J., Miller,T. R.,Zaloshnja, E. and Lawrence,B. A. 2015. "The economic and societal impact of motor vehicle crashes, 2010." (Revised)(Report No. DOT HS 812 013). Washington, DC: National Highway Traffic Safety Administration. 
[17] Bordignon, M., Nannicini, T. and G. Tabellini. 2017. "Single round vs. runoff elections under plurality rule: A theoretical analysis." European Journal of Political Economy. 49: 123-133.

[18] Bourgeon, J. and P. Picard. 2007. "Point-record driving license and road safety: An economic approach." Journal Of Public Economics. 91(1/2): 235-258.

[19] Bracco E. 2018. "A Fine Collection: The Political Budget Cycle of Traffic Enforcement". Economics Letters. 164: 117-120.

[20] Brender, A. and A. Drazen, 2005. "Political Budget Cycles In New Versus Established Democracies". Journal of Monetary Economics. 52: 1271-1295.

[21] Burgard, S., Ailshire, J. and L. Kalousova. 2013. "The Great Recession and Health: People, Populations, and Disparities." The ANNALS of the American Academy of Political and Social Science. 650(1): 194-213.

[22] Clark, A. E., and C. Milcent. 2011. "Public employment and political pressure: The case of French hospitals". Journal of Health Economics. 30: 1103-1112.

[23] Cohen, A. and L. Einav. 2003. "The effects of mandatory seat belt laws on driving behavior and traffic fatalities." Review of Economics and Statistics. 85 (4): 828-843.

[24] Cole, S. 2009. "Fixing Market Failures or Fixing Elections? Agricultural Credit in India". American Economic Journal: Applied Economics. 1:1, 219-250.

[25] Cotti, C. and N. Tefft. 2011. "Decomposing the Relationship between Macroeconomic Conditions and Fatal Car Crashes during the Great Recession: Alcohol- and Non-alcohol-Related Accidents." B.E. Journal Of Economic Analysis And Policy: Topics In Economic Analysis And Policy. 11, no. 1 (2011): EconLit, EBSCOhost (accessed September 8, 2018).

[26] Confcommercio. 2017. "Le determinanti dell'evasione fi scale: un'analisi regionale.", available at http://www.conf commercio.it/documents/10180/13595649/Le+determinanti+dell\% 27 evasione+fiscale.pdf/8fd55216-d0fc-4802-a2ef-c2254e0a56f6

[27] Drazen, A., and M. Eslava. 2010. "Electoral manipulation via expenditure composition: Theory and evidence". Journal of Development Economics. 92: 39-52.

[28] Englmaier, F. and T. Stowasser. 2017. "Electoral Cycles in Savings Bank Lending". Journal Of The European Economic Association. 15(2): 296-354.

[29] European Commission (EC). 2015. "Statistics on Road Safety", available at: http://ec.europa. eu/transport/road_safety/specialist/statistics/index_en.htm

[30] European Road Safety Observatory. 2017. "Annual Accident Report 2017", available at: https://ec.europa.eu/transport/road_safety/sites/roadsafety/files/pdf/statistics/ dacota/asr2017.pdf

[31] Foremny, D., and N. Riedel, 2014. "Business taxes and the electoral cycle." Journal Of Public Economics. 115: 48-61.

[32] Gagliarducci, S. and T. Nannicini. 2013. "Do Better Paid Politicians Perform Better? Disentangling Incentives from Selection." Journal Of The European Economic Association. 11(2): 369-398. 
[33] Gamalerio, M. 2019. Not Welcome Anymore: The Effect of Electoral Incentives on the Reception of Refugees. Mimeo April 2019

[34] Giulietti, C., Tonin, M. and M. Vlassopoulos. 2018. "When the market drives you crazy: Stock market returns and fatal car accidents." IZA Working Paper 11720.

[35] Grembi, V., Nannicini, T. and U. Troiano. 2017. "Do Fiscal Rules Matter?" American Economic Journal Applied Economics. 8(3):1-30.

[36] Gonzalez MdlA. 2000. "On Elections, Democracy, and Macroeconomic Policy: Evidence from Mexico." Work. Pap., Dept. Econ., Princeton Univ.

[37] Hahn, R. A., Kuzara, J. L., Elder, R., Brewer, R., Chattopadhyay,S., Fielding, J., Naimi, T. S., Toomey, T., Cook Middleton, J. and B. Lawrence. 2010. "Effectiveness of Policies Restricting Hours of Alcohol Sales in Preventing Excessive Alcohol Consumption and Related Harms." American Journal of Preventive Medicine. 39(6): 590.

[38] Law, T. H., Noland, R. B. and A. W. Evans. 2009. "Factors associated with the relationship between motorcycle deaths and economic growth." Accident Analysis \& Prevention. 41(2): 234-240.

[39] Miller, D., Page E. M., Huff A. and M. Filipskiand. 2009. "Why Are Recessions Good for Your Health?" American Economic Review: Papers $\& 3$ Proceedings . 99(2): 122-127.

[40] Parry, I.W. 2004. "Comparing alternative policies to reduce traffic accidents." Journal Urban Economics. 56(2): 346-368.

[41] Persson, T. and G. Tabellini, 2002. "Do Electoral Cycles Differ Across Political Systems?" working paper, IIES, Stockholm University.

[42] Regione Veneto - U.O. Sistema Statistico Regionale. 2014. "Gli incidenti stradali: le politiche, i costi e la dimensione". Statistical Report, available at: http://statistica.regione.veneto.it/ Pubblicazioni/RapportoStatistico2014/pdf/Capitolo14.pdf (accessed October 16, 2018).

[43] Romem, I. and I. Shurtz. 2016. "The accident externality of driving: Evidence from observance of the Jewish Sabbath in Israel." Journal of Urban Economics. 96: 36-54.

[44] Ruhm, C. J. 2000. "Are Recessions Good for Your Health?" The Quarterly Journal of Economics. 115(2): $617-650$.

[45] Shi, M., and J. Svensson. 2000. "Political business cycles in developed and developing countries." The World Bank. Working Paper.

[46] SITEB. 2012. "Dossier sul valore delle strade" Technical report.

[47] Stella, A., Nannicini, T., Tabellini, G., and U. Troiano. 2013. "Social capital and political accountability." American Economic Journal: Economic Policy. 5(2): 222-250.

[48] Takako, R., and S. Bessho, 2018. "Political Cycles in Physician Employment: A Case of Japanese Local Public Hospitals." Social Science and Medicine, forthcoming.

[49] Wales, J. 2017. "The Political economy of Road Safety. A policy Oriented Literature Review". ODI Report. 61:877-881. 
[50] World Health Organization (WHO). 2015. "Global status report on road safety 2015", available at: http://www.who.int/violence_injury_prevention/road_safety_status/2015/en/ 


\section{Appendix A: Additional Tables and Figures}

Figure A.1: Lombardy and Veneto

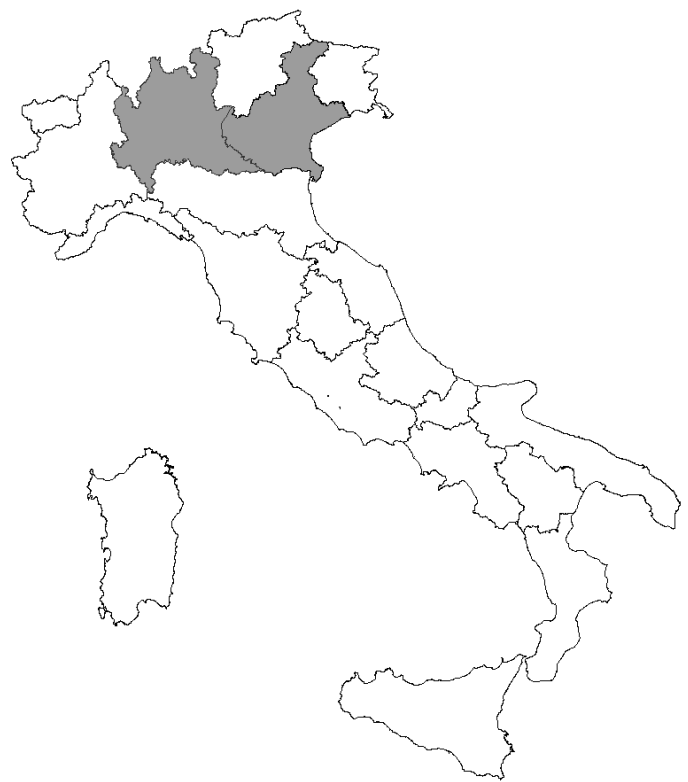

Notes: The gray areas indicate the two regions under study: Lombardy and Veneto.

Figure A.2: Emergency calls and accidents per municipality (Lombardy 2008-2016)

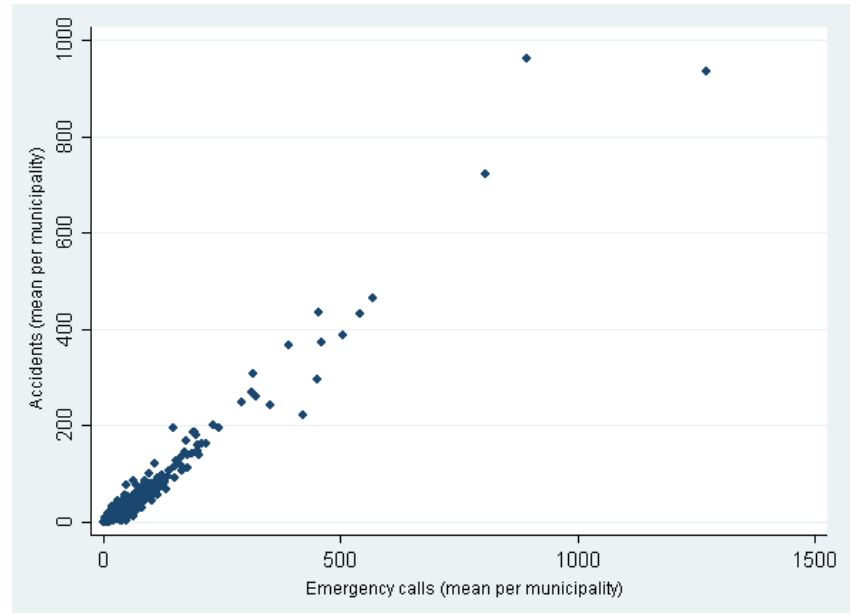

Notes: Data on the emergency calls related to road traffic accidents were provided only for Lombardy and the period of 2008-2016 by the regional agency (Agenzia Regionale Emergenza Urgenza-AREU) in charge of 112 (the emergency number). Each dot represents a municipality in our Lombardy dataset; Milan is dropped in this figure. 
Figure A.3: Municipalities with more than 1,000 residents

(a)

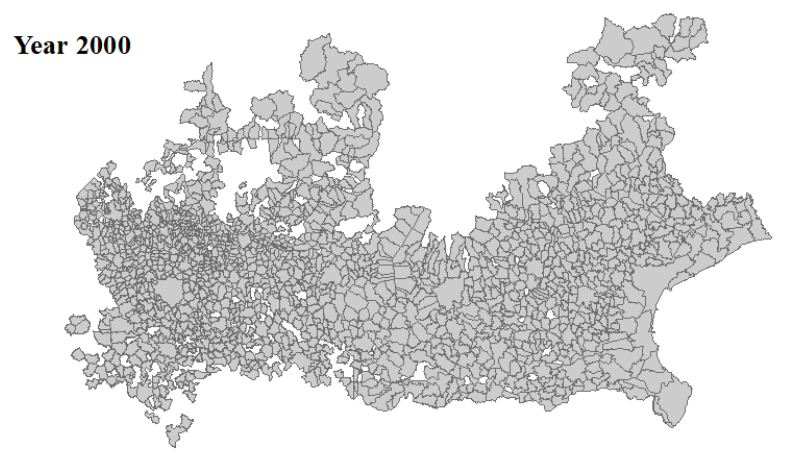

(b)

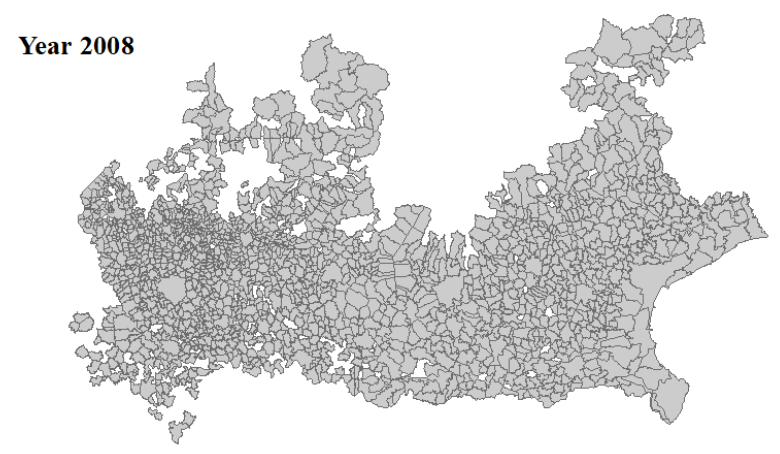

(c)

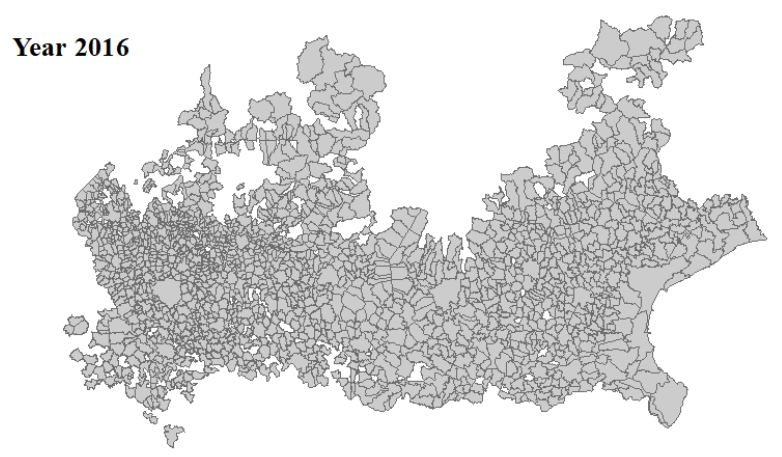

Notes: The plotted coefficients refer to the election year. For a description of the variables, see Table A.1 
Figure A.4: Population density

\section{Population density:}

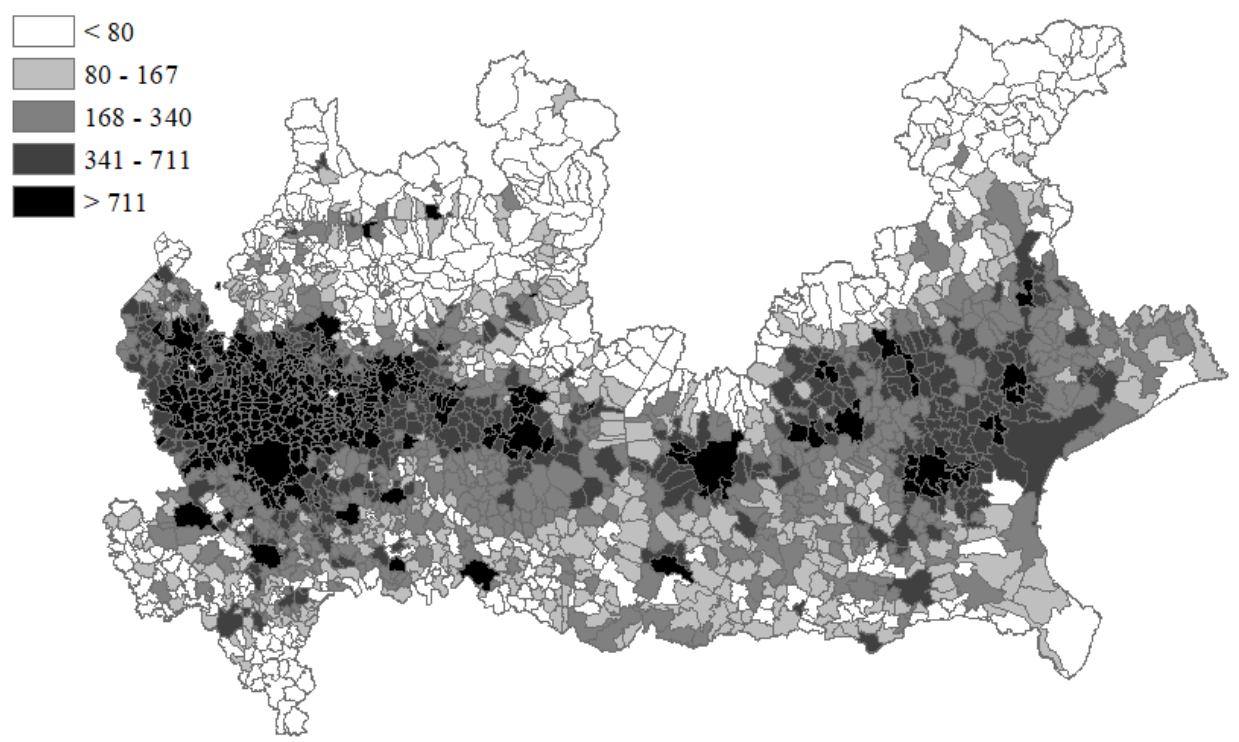

Notes: The map shows population densities at municipal levels in Lombardy and Veneto using 2008 as an example year.

Figure A.5: Lesivity and fatality rates per type of accident

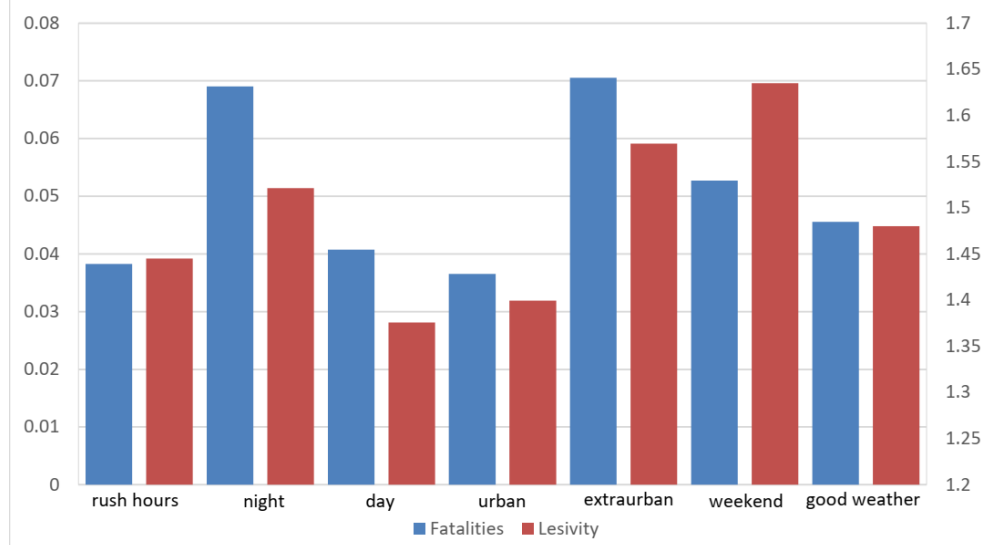

Notes: The fatality rate is calculated here as the number of deaths per types of accident. The lesivity rate measures the number of dead and injured per accident type. 
Table A.1: Variable definitions

\begin{tabular}{|c|c|c|c|}
\hline Variable Name & Variable Description & Source & Time \\
\hline \multicolumn{4}{|l|}{ Main Outcomes } \\
\hline Accident Rate & $\begin{array}{l}\text { Number of accidents over the } \\
\text { resident population per } 1000\end{array}$ & $\begin{array}{l}\text { Eupolis \& Statistical } \\
\text { office of Veneto region }\end{array}$ & $\begin{array}{l}\text { Year \& } \\
\text { Quarter }\end{array}$ \\
\hline Fatality Rate & $\begin{array}{l}\text { Number of deaths over the } \\
\text { resident population per } 1000\end{array}$ & $\begin{array}{l}\text { Eupolis \& Statistical } \\
\text { office of Veneto region }\end{array}$ & $\begin{array}{l}\text { Year \& } \\
\text { Quarter }\end{array}$ \\
\hline Injury Rate & $\begin{array}{l}\text { Number of injured over the } \\
\text { resident population per } 1000\end{array}$ & $\begin{array}{l}\text { Eupolis \& Statistical } \\
\text { office of Veneto region }\end{array}$ & $\begin{array}{l}\text { Year \& } \\
\text { Quarter }\end{array}$ \\
\hline \multicolumn{4}{|l|}{ Controls } \\
\hline Altitude & Altitude of the municipal territory & ISTAT & Year \\
\hline Coastal & $\begin{array}{l}\text { Dummy equal to } 1 \text { if the municipality is } \\
\text { coastal, } 0 \text { otherwise }\end{array}$ & ISTAT & Year \\
\hline Population Density & $\begin{array}{l}\text { Resident population over the municipal } \\
\text { area in squared kilometers }\end{array}$ & ISTAT & Year \\
\hline Female Mayor & Dummy equal to 1 if the mayor is a female & MoI & Year \\
\hline Educated Mayor & $\begin{array}{l}\text { Dummy equal to } 1 \text { if the mayor holds a high } \\
\text { school degree or a college degree }\end{array}$ & MoI & Year \\
\hline Same Municipality & $\begin{array}{l}\text { Dummy equal to } 1 \text { if the mayor } \\
\text { governs her municipality of birth }\end{array}$ & MoI & Year \\
\hline \multicolumn{4}{|c|}{ Yearly Budget Outcomes } \\
\hline Ticket Rate & $\begin{array}{l}\text { Number of fines over the resident } \\
\text { population per } 100\end{array}$ & MoI & Year \\
\hline Ticket Revenues & $\begin{array}{l}\text { Money collected through fines over } \\
\text { the resident population per } 100 \text { (log) }\end{array}$ & MoI & Year \\
\hline Police Expenditures & $\begin{array}{l}\text { Expenditures on local police activities } \\
\text { over the resident population per } 100\end{array}$ & MoI & Year \\
\hline Road safety Expenditures & $\begin{array}{l}\text { Expenditures on road safety activities } \\
\text { over the resident population per } 100\end{array}$ & MoI & Year \\
\hline Lights & $\begin{array}{l}\text { Number of public lights normalized on the } \\
\text { resident population }\end{array}$ & MoI & Year \\
\hline $\mathrm{kWh}$ Used & $\begin{array}{l}\text { Number of public kilowatts consumed per hour } \\
\text { normalized on the resident population }\end{array}$ & MoI & Year \\
\hline \multicolumn{4}{|c|}{ Type of accidents, injured, and deaths } \\
\hline Rush hours & Accidents taking place between $7-9 \mathrm{am}$ and $5-8 \mathrm{pm}$ & $\begin{array}{l}\text { Eupolis \& Statistical } \\
\text { office of Veneto region }\end{array}$ & Year \\
\hline Good Weather & Accidents taking place under good weather conditions & $\begin{array}{l}\text { Eupolis \& Statistical } \\
\text { office of Veneto region }\end{array}$ & Year \\
\hline Day & Accidents taking place during the day & $\begin{array}{l}\text { Eupolis \& Statistical } \\
\text { office of Veneto region }\end{array}$ & Year \\
\hline Night & Accidents taking place at the night & $\begin{array}{l}\text { Eupolis \& Statistical } \\
\text { office of Veneto region }\end{array}$ & Year \\
\hline Weekend & Accidents taking place on Sunday and Saturday & $\begin{array}{l}\text { Eupolis \& Statistical } \\
\text { office of Veneto region }\end{array}$ & Year \\
\hline Urban & Accidents taking place on urban roads & $\begin{array}{l}\text { Eupolis \& Statistical } \\
\text { office of Veneto region }\end{array}$ & Year \\
\hline Rural & Accidents taking place on rural roads & $\begin{array}{l}\text { Eupolis \& Statistical } \\
\text { office of Veneto region }\end{array}$ & Year \\
\hline
\end{tabular}

Notes: Eupolis=Institute for research, statistics and training of Lombardy. MoI= Italian Ministry of the Interior. $I S T A T=$ Italian Institute of Statistics. 
Table A.2: Road traffic accidents: results for the sample with all municipalities

\begin{tabular}{|c|c|c|c|c|c|c|}
\hline & \multicolumn{2}{|c|}{$\begin{array}{c}\text { Accident } \\
\text { rate }\end{array}$} & \multicolumn{2}{|c|}{$\begin{array}{l}\text { Injury } \\
\text { rate }\end{array}$} & \multicolumn{2}{|c|}{$\begin{array}{c}\text { Fatality } \\
\text { rate }\end{array}$} \\
\hline & $(1)$ & $(2)$ & $(3)$ & $(4)$ & $(5)$ & $(6)$ \\
\hline \multicolumn{7}{|c|}{ PANEL A: Municipal FE } \\
\hline Election Year & $\begin{array}{c}0.032 \\
(0.024)\end{array}$ & $\begin{array}{c}0.032 \\
(0.024)\end{array}$ & $\begin{array}{l}0.063^{*} \\
(0.035)\end{array}$ & $\begin{array}{l}0.063 * \\
(0.035)\end{array}$ & $\begin{array}{c}0.000 \\
(0.003)\end{array}$ & $\begin{array}{c}0.000 \\
(0.003)\end{array}$ \\
\hline Pop Density & No & Yes & No & Yes & No & Yes \\
\hline Year FE & Yes & Yes & Yes & Yes & Yes & Yes \\
\hline Observations & 38,368 & 38,302 & 38,368 & 38,302 & 38,368 & 38,302 \\
\hline Mean & 2.570 & 2.570 & 3.742 & 3.742 & 0.116 & 0.116 \\
\hline
\end{tabular}

PANEL B: Provincial FE

\begin{tabular}{|c|c|c|c|c|c|c|}
\hline Election Year & $\begin{array}{c}0.058^{* * *} \\
(0.023)\end{array}$ & $\begin{array}{c}0.052^{* *} \\
(0.023)\end{array}$ & $\begin{array}{c}0.095^{* * *} \\
(0.034)\end{array}$ & $\begin{array}{c}0.085^{* *} \\
(0.035)\end{array}$ & $\begin{array}{c}0.000 \\
(0.003)\end{array}$ & $\begin{array}{c}0.000 \\
(0.003)\end{array}$ \\
\hline Pop Density & No & Yes & No & Yes & No & Yes \\
\hline TI Controls & No & Yes & No & Yes & No & Yes \\
\hline Year FE & Yes & Yes & Yes & Yes & Yes & Yes \\
\hline Observations & 38,368 & 38,302 & 38,368 & 38,302 & 38,368 & 38,302 \\
\hline Mean & 2.570 & 2.570 & 3.742 & 3.742 & 0.116 & 0.116 \\
\hline \multicolumn{7}{|c|}{ PANEL C: LLM FE } \\
\hline Election Year & $\begin{array}{c}0.054^{* *} \\
(0.024)\end{array}$ & $\begin{array}{c}0.050^{* *} \\
(0.024)\end{array}$ & $\begin{array}{c}0.089 * * \\
(0.041)\end{array}$ & $\begin{array}{c}0.083^{* *} \\
(0.040)\end{array}$ & $\begin{array}{l}-0.000 \\
(0.004)\end{array}$ & $\begin{array}{c}0.000 \\
(0.004)\end{array}$ \\
\hline Pop Density & No & Yes & No & Yes & No & Yes \\
\hline TI Dontrols & No & Yes & No & Yes & No & Yes \\
\hline Year FE & Yes & Yes & Yes & Yes & Yes & Yes \\
\hline Observations & 38,368 & 38,302 & 38,368 & 38,302 & 38,368 & 38,302 \\
\hline Mean & 2.570 & 2.570 & 3.742 & 3.742 & 0.116 & 0.116 \\
\hline
\end{tabular}

Notes: TI controls=controls for altitude, whether the municipality is coastal, and the number of national and local police stations. $L L M$ stands for Local Labor Markets. For a description of the variables, see Table A.1 Standard errors are clustered at the provincial level. *** $\mathrm{p}<0.01$, ** $\mathrm{p}<0.05$, and $* \mathrm{p}<0.1$. 
Table A.3: Composition of tickets for a few municipalities

\begin{tabular}{|c|c|c|c|c|}
\hline & $\begin{array}{c}\text { Minor } \\
\text { Violations } \\
\end{array}$ & $\begin{array}{c}\text { Serious } \\
\text { Violations } \\
\end{array}$ & $\begin{array}{c}\text { Parking } \\
\text { tickets }\end{array}$ & $\overline{\mathrm{KM}}$ \\
\hline & $(1)$ & $(2)$ & $(3)$ & $(4)$ \\
\hline \multicolumn{5}{|c|}{ PANEL A: Municipal Election } \\
\hline Election year & $\begin{array}{c}-0.014^{*} \\
(0.008)\end{array}$ & $\begin{array}{c}0.018 \\
(0.059)\end{array}$ & $\begin{array}{c}-0.017^{* *} \\
(0.009)\end{array}$ & $\begin{array}{c}5.193 \\
(20.847)\end{array}$ \\
\hline Municipality FE & Yes & Yes & Yes & Yes \\
\hline Year FE & Yes & Yes & Yes & Yes \\
\hline Observations & 315 & 305 & 259 & 166 \\
\hline \multicolumn{5}{|c|}{ PANEL B: National Election } \\
\hline Election year & $\begin{array}{c}0.079 \\
(0.055)\end{array}$ & $\begin{array}{c}0.244^{* * *} \\
(0.093)\end{array}$ & $\begin{array}{c}0.163^{* * *} \\
(0.04)\end{array}$ & $\begin{array}{c}95.773^{* *} \\
(45.809)\end{array}$ \\
\hline Municipality FE & Yes & Yes & Yes & Yes \\
\hline Year FE & Yes & Yes & Yes & Yes \\
\hline Observations & 315 & 305 & 259 & 152 \\
\hline
\end{tabular}

Notes: This table is based on data we recovered from reports on the activities of the local police for approximately 30 municipalities, and the period mainly covers more recent years (2008-2018). The outcomes are normalized on the resident population. MinorViolations comprises violations of road regulations, which are not necessarily associated with criminal behavior (e.g., entering with no permission in restricted traffic zones or parking violations), of which Parkingtickets are a subgroup. $K M$ is the number of kilometers registered by the local police. SeriousViolations comprise driving under the influence of drug and/or alcohol and speed limits violations. $* * * \mathrm{p}<0.01$, ** $\mathrm{p}<0.05$, and $* \mathrm{p}<0.1$.

Figure A.6: Distribution of the outcomes of interest per quarter

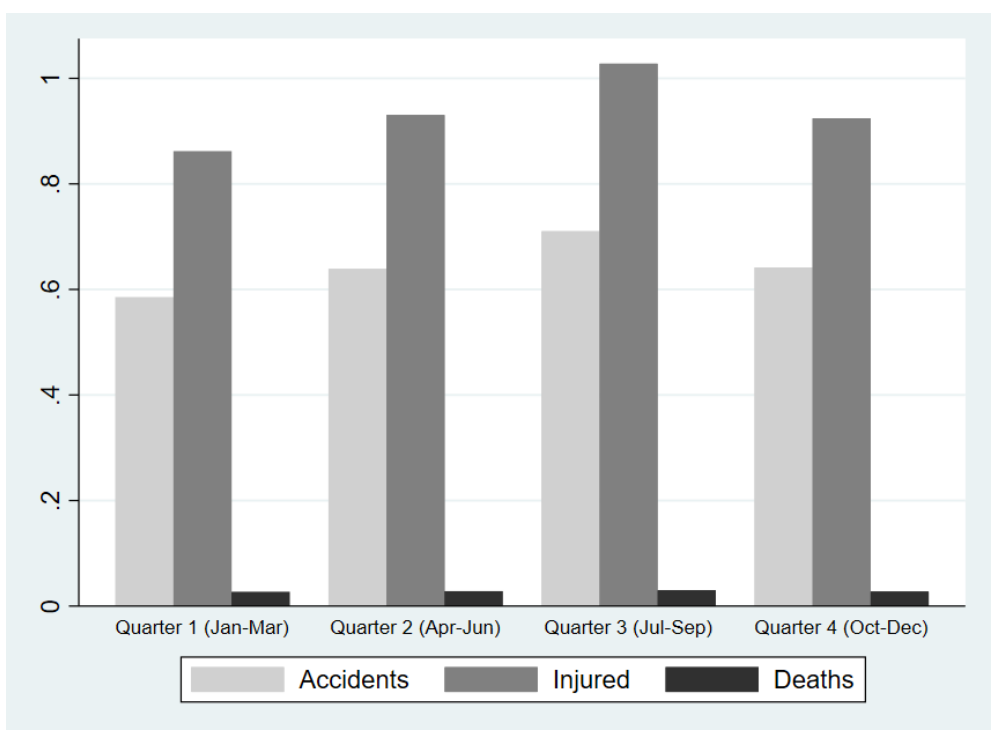

Notes: The figure shows the distributions of the main outcomes of interest per quarter. 
Table A.4: Effects of quarters

\begin{tabular}{|c|c|c|c|}
\hline & $\begin{array}{c}\text { Accident } \\
\text { rate }\end{array}$ & $\begin{array}{c}\text { Injury } \\
\text { rate }\end{array}$ & $\begin{array}{c}\text { Fatality } \\
\text { rate }\end{array}$ \\
\hline & $(1)$ & $(2)$ & $(3)$ \\
\hline \multicolumn{4}{|c|}{ PANEL A: Jan-Mar as the reference quarter } \\
\hline Quarter 2 (Apr-Jun) & $\begin{array}{c}0.054^{* *} \\
(0.022)\end{array}$ & $\begin{array}{c}0.069^{* *} \\
(0.033)\end{array}$ & $\begin{array}{c}0.002 \\
(0.001)\end{array}$ \\
\hline Quarter 3 (Jul-Sep) & $\begin{array}{c}0.125^{* * *} \\
(0.021)\end{array}$ & $\begin{array}{c}0.166^{* * *} \\
(0.03)\end{array}$ & $\begin{array}{c}0.003^{*} \\
(0.002)\end{array}$ \\
\hline Quarter 4 (Oct-Dec) & $\begin{array}{c}0.056^{* * *} \\
(0.014)\end{array}$ & $\begin{array}{c}0.063^{* * * *} \\
(0.02)\end{array}$ & $\begin{array}{c}0.001 \\
(0.001) \\
\end{array}$ \\
\hline \multicolumn{4}{|c|}{ PANEL B: Oct-Dec as the reference quarter } \\
\hline Quarter 1 (Jan-Mar) & $\begin{array}{c}-0.056^{* * *} \\
(0.014)\end{array}$ & $\begin{array}{c}-0.063^{* * *} \\
(0.02)\end{array}$ & $\begin{array}{c}-0.001 \\
(0.001)\end{array}$ \\
\hline Quarter 2 (Apr-Jun) & $\begin{array}{l}-0.003 \\
(0.017)\end{array}$ & $\begin{array}{c}0.006 \\
(0.024)\end{array}$ & $\begin{array}{c}0.001 \\
(0.001)\end{array}$ \\
\hline Quarter 3 (Jul-Sep) & $\begin{array}{c}0.069^{* * *} \\
(0.018) \\
\end{array}$ & $\begin{array}{c}0.104^{* * *} \\
(0.027) \\
\end{array}$ & $\begin{array}{c}0.002 \\
(0.001) \\
\end{array}$ \\
\hline \multicolumn{4}{|c|}{ PANEL C: Jul-Sep as the reference quarter } \\
\hline Quarter 1 (Jan-Mar) & $\begin{array}{c}-0.125^{* * *} \\
(0.021)\end{array}$ & $\begin{array}{c}-0.166^{* * *} \\
(0.03)\end{array}$ & $\begin{array}{c}-0.003^{*} \\
(0.002)\end{array}$ \\
\hline Quarter 2 (Apr-Jun) & $\begin{array}{c}-0.071^{* * *} \\
(0.019)\end{array}$ & $\begin{array}{c}-0.097^{* * *} \\
(0.027)\end{array}$ & $\begin{array}{c}-0.002 \\
(0.001)\end{array}$ \\
\hline Quarter 4 (Oct-Dec) & $\begin{array}{c}-0.069^{* * *} \\
(0.018) \\
\end{array}$ & $\begin{array}{c}-0.104^{* * *} \\
(0.027) \\
\end{array}$ & $\begin{array}{l}-0.002 \\
(0.001) \\
\end{array}$ \\
\hline Municipality FE & Yes & Yes & Yes \\
\hline Year FE & Yes & Yes & Yes \\
\hline Mean & 0.644 & 0.936 & 0.028 \\
\hline Observations & 130,984 & 130,9844 & 130,984 \\
\hline
\end{tabular}

Notes: Standard errors are clustered at the provincial level. *** $\mathrm{p}<0.01,{ }^{* *} \mathrm{p}<0.05$, and ${ }^{*} \mathrm{p}<0.1$. 
Table A.5: Descriptive statistics

\begin{tabular}{|c|c|c|c|c|}
\hline \multirow[b]{2}{*}{ Variable Name } & \multicolumn{2}{|c|}{ All } & \multicolumn{2}{|c|}{$\begin{array}{l}\text { Above } 1000 \\
\text { inhabitants }\end{array}$} \\
\hline & Mean & Std. & Mean & Std. \\
\hline \multicolumn{5}{|l|}{ Main Outcomes } \\
\hline Accident Rate & 2.570 & 2.612 & 2.625 & 2.087 \\
\hline Fatality Rate & 0.116 & 0.339 & 0.111 & 0.250 \\
\hline Injury Rate & 3.742 & 4.026 & 3.080 & 3.213 \\
\hline \multicolumn{5}{|l|}{ Controls } \\
\hline Altitude & 247.057 & 272.034 & 200.820 & 223.303 \\
\hline Coastal & 0.006 & 0.076 & 0.007 & 0.084 \\
\hline Population Density & 452.192 & 665.952 & 528.815 & 705.092 \\
\hline Local Police & 0.537 & 0.499 & 0.892 & 0.491 \\
\hline National Police & 0.285 & 0.452 & 0.338 & 0.473 \\
\hline Distance National Police & 4.732 & 90.103 & 4.854 & 98.710 \\
\hline Female Mayor & 0.127 & 0.333 & 0.133 & 0.339 \\
\hline Educated Mayor & 0.847 & 0.360 & 0.871 & 0.336 \\
\hline Same Municipality & 0.368 & 0.482 & 0.380 & 0.486 \\
\hline \multicolumn{5}{|l|}{ Yearly Budget Outcomes } \\
\hline Ticket Rate & 1.759 & 20.521 & 1.752 & 4.888 \\
\hline Ticket Revenues & 1.173 & 1.647 & 1.254 & 1.591 \\
\hline Police Expenditures & 9.709 & 1.007 & 9.701 & 0.898 \\
\hline Road Safety Expenditures & 10.551 & 0.598 & 10.505 & 0.559 \\
\hline Lights & 18.120 & 14.326 & 17.291 & 13.706 \\
\hline Kw Hour Used & 11.109 & 16.934 & 10.524 & 16.797 \\
\hline \multicolumn{5}{|l|}{ Type of accidents } \\
\hline Rush Hours & 8.564 & 102.388 & 10.200 & 111.772 \\
\hline Good Weather & 21.700 & 260.264 & 25.702 & 284.133 \\
\hline Day & 17.265 & 216373 & 20.565 & 236.219 \\
\hline Night & 4.590 & 84.224 & 5.468 & 91.978 \\
\hline Weekend & 6.789 & 70.084 & 8.049 & 76.494 \\
\hline Urban & 7.599 & 123.051 & 9.119 & 134.864 \\
\hline Rural & 2.719 & 9.636 & 3.241 & 10.483 \\
\hline \multicolumn{5}{|l|}{ Type of injured } \\
\hline Rush Hours & 11.352 & 128.394 & 13.517 & 140.152 \\
\hline Good Weather & 229.441 & 343.017 & 34.849 & 374.432 \\
\hline Day & 21.566 & 271.722 & 25.682 & 296.647 \\
\hline Night & 6.716 & 126.732 & 8.000 & 138.403 \\
\hline Weekend & 10.468 & 105.335 & 12.408 & 114.963 \\
\hline Urban & 9.954 & 145.921 & 11.946 & 159.916 \\
\hline Rural & 4.215 & 15.324 & 5.023 & 16.676 \\
\hline \multicolumn{5}{|l|}{ Type of dead } \\
\hline Rush Hours & 0.143 & 0.684 & 0.169 & 0.743 \\
\hline Good Weather & 0.343 & 1.837 & 0.422 & 2.064 \\
\hline Day & 0.258 & 01.260 & 0.306 & 1.370 \\
\hline Night & 0.142 & 0.948 & 0.169 & 1.033 \\
\hline Weekend & 0.201 & 0.801 & 0.237 & 0.869 \\
\hline Urban & 0.141 & 1.004 & 0.168 & 1.098 \\
\hline Rural & 0.164 & 0.649 & 0.195 & 0.706 \\
\hline
\end{tabular}

Notes: For a description of the variables, see Table A.1 
Table A.6: Road traffic accidents: results around election year with trends

\begin{tabular}{|c|c|c|c|c|c|c|}
\hline & \multicolumn{2}{|c|}{$\begin{array}{c}\text { Accident } \\
\text { rate }\end{array}$} & \multicolumn{2}{|c|}{$\begin{array}{c}\text { Injury } \\
\text { rate }\end{array}$} & \multicolumn{2}{|c|}{$\begin{array}{c}\text { Fatality } \\
\text { rate }\end{array}$} \\
\hline & $\begin{array}{l}\text { Provincial } \\
\text { trend }\end{array}$ & $\begin{array}{l}\text { LLM } \\
\text { trend }\end{array}$ & $\begin{array}{l}\text { Provincial } \\
\text { trend }\end{array}$ & $\begin{array}{l}\text { LLM } \\
\text { trend }\end{array}$ & $\begin{array}{l}\text { Provincial } \\
\text { trend }\end{array}$ & $\begin{array}{l}\text { LLM } \\
\text { trend }\end{array}$ \\
\hline Before & $\begin{array}{c}0.009 \\
(0.020)\end{array}$ & $\begin{array}{c}0.009 \\
(0.022)\end{array}$ & $\begin{array}{c}0.006 \\
(0.032)\end{array}$ & $\begin{array}{c}0.005 \\
(0.034)\end{array}$ & $\begin{array}{l}-0.006 \\
(0.004)\end{array}$ & $\begin{array}{l}-0.006 \\
(0.004)\end{array}$ \\
\hline Election year & $\begin{array}{l}0.041^{*} \\
(0.021)\end{array}$ & $\begin{array}{c}0.041^{* *} \\
(0.018)\end{array}$ & $\begin{array}{c}0.073^{* *} \\
(0.032)\end{array}$ & $\begin{array}{c}0.072^{* *} \\
(0.032)\end{array}$ & $\begin{array}{c}0.002 \\
(0.003)\end{array}$ & $\begin{array}{c}0.003 \\
(0.003)\end{array}$ \\
\hline After & $\begin{array}{c}0.010 \\
(0.017) \\
\end{array}$ & $\begin{array}{c}0.011 \\
(0.019) \\
\end{array}$ & $\begin{array}{c}0.001 \\
(0.027) \\
\end{array}$ & $\begin{array}{c}0.002 \\
(0.035) \\
\end{array}$ & $\begin{array}{l}-0.006 \\
(0.004) \\
\end{array}$ & $\begin{array}{c}-0.006 \\
(0.004) \\
\end{array}$ \\
\hline Pop Density & No & Yes & No & Yes & No & Yes s \\
\hline Year FE & Yes & Yes & Yes & Yes & Yes & Yes \\
\hline Municipal FE & Yes & Yes & Yes & Yes & Yes & Yes \\
\hline Observations & 31,916 & 31,909 & 31,916 & 31,909 & 31,916 & 31,909 \\
\hline Mean & 2.623 & 2.625 & 3.806 & 3.808 & 0.111 & 0.111 \\
\hline
\end{tabular}

Notes: Before is equal to 1 for the year before an election, while After is a dummy for the year after an election. The terms are 4 years until 2001 and 5 years after 2001. $L L M$ stands for Local Labor Markets. Standard errors are clustered at the provincial level. *** $\mathrm{p}<0.01, * * \mathrm{p}<0.05$, and * $\mathrm{p}<0.1$. 
Appendix B: Model with Provincial Fixed Effects

Table B.1: Road traffic accidents: results around the election year

\begin{tabular}{|c|c|c|c|c|c|c|c|c|c|}
\hline & \multicolumn{3}{|c|}{$\begin{array}{c}\text { Accident } \\
\text { rate }\end{array}$} & \multicolumn{3}{|c|}{$\begin{array}{c}\text { Injury } \\
\text { rate }\end{array}$} & \multicolumn{3}{|c|}{$\begin{array}{c}\text { Fatality } \\
\text { rate }\end{array}$} \\
\hline Before & $\begin{array}{c}0.006 \\
(0.020)\end{array}$ & $\begin{array}{c}0.008 \\
(0.019)\end{array}$ & $\begin{array}{c}0.010 \\
(0.020)\end{array}$ & $\begin{array}{l}-0.001 \\
(0.035)\end{array}$ & $\begin{array}{c}0.002 \\
(0.034)\end{array}$ & $\begin{array}{c}0.007 \\
(0.035)\end{array}$ & $\begin{array}{l}-0.006 \\
(0.004)\end{array}$ & $\begin{array}{l}-0.006 \\
(0.004)\end{array}$ & $\begin{array}{l}-0.006 \\
(0.004)\end{array}$ \\
\hline Election Year & $\begin{array}{c}0.068^{* * *} * \\
(0.021)\end{array}$ & $\begin{array}{c}0.062^{* * *} \\
(0.019)\end{array}$ & $\begin{array}{c}0.062^{* * *} \\
(0.021)\end{array}$ & $\begin{array}{c}0.105^{* * *} \\
(0.034)\end{array}$ & $\begin{array}{c}0.098 * * \\
(0.032)\end{array}$ & $\begin{array}{c}0.097^{* *} \\
(0.035)\end{array}$ & $\begin{array}{c}0.002 \\
(0.003)\end{array}$ & $\begin{array}{c}0.002 \\
(0.003)\end{array}$ & $\begin{array}{c}0.002 \\
(0.003)\end{array}$ \\
\hline After & $\begin{array}{c}0.016 \\
(0.016) \\
\end{array}$ & $\begin{array}{c}0.018 \\
(0.018) \\
\end{array}$ & $\begin{array}{c}0.021 \\
(0.015) \\
\end{array}$ & $\begin{array}{c}0.016 \\
(0.026) \\
\end{array}$ & $\begin{array}{c}0.017 \\
(0.017) \\
\end{array}$ & $\begin{array}{c}0.021 \\
(0.026) \\
\end{array}$ & $\begin{array}{c}-0.005 \\
(0.004) \\
\end{array}$ & $\begin{array}{l}-0.006 \\
(0.004) \\
\end{array}$ & $\begin{array}{c}-0.006 \\
(0.004) \\
\end{array}$ \\
\hline Pop Density & No & Yes & Yes & No & Yes & Yes & No & Yes & Yes \\
\hline TI Controls & No & Yes & Yes & No & Yes & Yes & No & Yes & Yes \\
\hline Year FE & Yes & Yes & Yes & Yes & Yes & Yes & Yes & Yes & Yes \\
\hline Provincial FE & Yes & Yes & Yes & Yes & Yes & Yes & Yes & Yes & Yes \\
\hline Provincial Trends & No & No & Yes & No & No & Yes & No & No & Yes \\
\hline Observations & 31,865 & 31,865 & 31,865 & 31,865 & 31,865 & 31,865 & 31,865 & 31,865 & 31,865 \\
\hline Mean & 2.623 & 2.625 & 2.625 & 3.806 & 3.808 & 3.808 & 0.111 & 0.111 & 0.111 \\
\hline
\end{tabular}

Notes: Before is equal to 1 for the year before an election, while After is a dummy for the year after an election. The terms are 4 years until 2001 and 5 years after 2001. Only municipalities with or above 1,000 inhabitants are included. TI controls= controls for altitude, whether the municipality is coastal, and the number of national and local police stations. For a description of the variables, see Table A.1 Standard errors are clustered at the provincial level. ${ }^{* * *} \mathrm{p}<0.01, * * \mathrm{p}<0.05$, and $* \mathrm{p}<0.1$.

Table B.2: Road traffic accidents: results at the quarterly level

\begin{tabular}{lcccccc}
\hline \hline & \multicolumn{2}{c}{$\begin{array}{c}\text { Accident } \\
\text { rate }\end{array}$} & \multicolumn{2}{c}{$\begin{array}{c}\text { Injury } \\
\text { rate }\end{array}$} & $\begin{array}{c}\text { Fatality } \\
\text { rate }\end{array}$ \\
\hline \hline & & & & \\
Quarter -2 & $0.054^{* *}$ & $0.044^{*}$ & $0.097^{* *}$ & $0.094^{* *}$ & -0.002 & -0.002 \\
& $(0.022)$ & $(0.023)$ & $(0.043)$ & $(0.042)$ & $(0.004)$ & $(0.004)$ \\
Quarter -1 & $0.091^{* * *}$ & $0.077^{* *}$ & $0.164^{* * *}$ & $0.163^{* * *}$ & 0.001 & 0.002 \\
& $(0.029)$ & $(0.035)$ & $(0.048)$ & $(0.051)$ & $(0.004)$ & $(0.004)$ \\
Quarter 0 & $-0.040^{* *}$ & $-0.040^{*}$ & -0.005 & -0.001 & 0.002 & 0.002 \\
& $(0.018)$ & $(0.023)$ & $(0.037)$ & $(0.037)$ & $(0.003)$ & $(0.003)$ \\
Quarter 1 & 0.01713 & -0.001 & 0.032 & 0.025 & 0.001 & 0.001 \\
& $(0.011)$ & $(0.014)$ & $(0.021)$ & $(0.022)$ & $(0.003)$ & $(0.003)$ \\
Quarter 2 & $0.092^{* * *}$ & $0.063^{* *}$ & $0.162^{* * *}$ & $0.151^{* * *}$ & 0.0016 & 0.001 \\
& $(0.022)$ & $(0.025)$ & $(0.044)$ & $(0.044)$ & $(0.004)$ & $(0.004)$ \\
\hline \multirow{2}{*}{ Quarter FE } & Yes & Yes & Yes & Yes & Yes & Yes \\
Year FE & Yes & Yes & Yes & Yes & Yes & Yes \\
Provincial FE & No & Yes & No & Yes & No & Yes \\
Provincial Trends & No & Yes & No & Yes & No & Yes \\
TV Controls & No & Yes & No & Yes & No & Yes \\
TI Controls & No & Yes & No & Yes & No & Yes \\
\hline
\end{tabular}

Notes: The reference quarter is Quarter - 3, which means 9 months before the election quarter. TV controls $=$ controls for population density and the presence of units of both local and state police. $T I$ controls $=$ controls for both altitude and whether the municipality is coastal. For a description of the variables, see Table A.1 Standard errors are clustered at the provincial level. ${ }^{* * *} \mathrm{p}<0.01, * *$ $\mathrm{p}<0.05$, and $* \mathrm{p}<0.1$. 
Table B.3: Road traffic accidents over the national election cycle

\begin{tabular}{|c|c|c|c|c|c|c|}
\hline \multirow[b]{2}{*}{ Election Year } & \multicolumn{2}{|c|}{$\begin{array}{c}\text { Accident } \\
\text { rate }\end{array}$} & \multicolumn{2}{|c|}{$\begin{array}{c}\text { Injury } \\
\text { rate }\end{array}$} & \multicolumn{2}{|c|}{$\begin{array}{c}\text { Fatality } \\
\text { rate }\end{array}$} \\
\hline & $\begin{array}{c}(1) \\
-0.043^{* * *} \\
(0.008) \\
\end{array}$ & $\begin{array}{c}(2) \\
-0.026 \\
(0.019)\end{array}$ & $\begin{array}{c}(3) \\
-0.061^{* * *} \\
(0.010)\end{array}$ & $\begin{array}{c}(4) \\
-0.027 \\
(0.027)\end{array}$ & $\begin{array}{c}(5) \\
-0.009 * * * \\
(0.001) \\
\end{array}$ & $\begin{array}{c}(6) \\
-0.008^{* * *} \\
(0.002) \\
\end{array}$ \\
\hline Pop Density & Yes & Yes & Yes & Yes & Yes & Yes \\
\hline TI Controls & Yes & Yes & Yes & Yes & Yes & Yes \\
\hline Year FE & Yes & Yes & Yes & Yes & Yes & Yes \\
\hline Provincial FE & Yes & Yes & Yes & Yes & Yes & Yes \\
\hline Provincial Trends & No & Yes & No & Yes & No & Yes \\
\hline Observations & 31,863 & 31,863 & 31,863 & 31,863 & 31,863 & 31,863 \\
\hline Mean & 2.262 & 2.262 & 3.808 & 3.808 & 0.111 & 0.111 \\
\hline
\end{tabular}

Notes: TI controls = controls for altitude, whether the municipality is coastal, and the number of national and local police stations. For a description of the variables, see Table A.1 The national elections are considered to occur in 1996, 2001, 2006, 2008, and 2013. Standard errors are clustered at the provincial level. *** $\mathrm{p}<0.01, * * \mathrm{p}<0.05$, and $* \mathrm{p}<0.1$. 


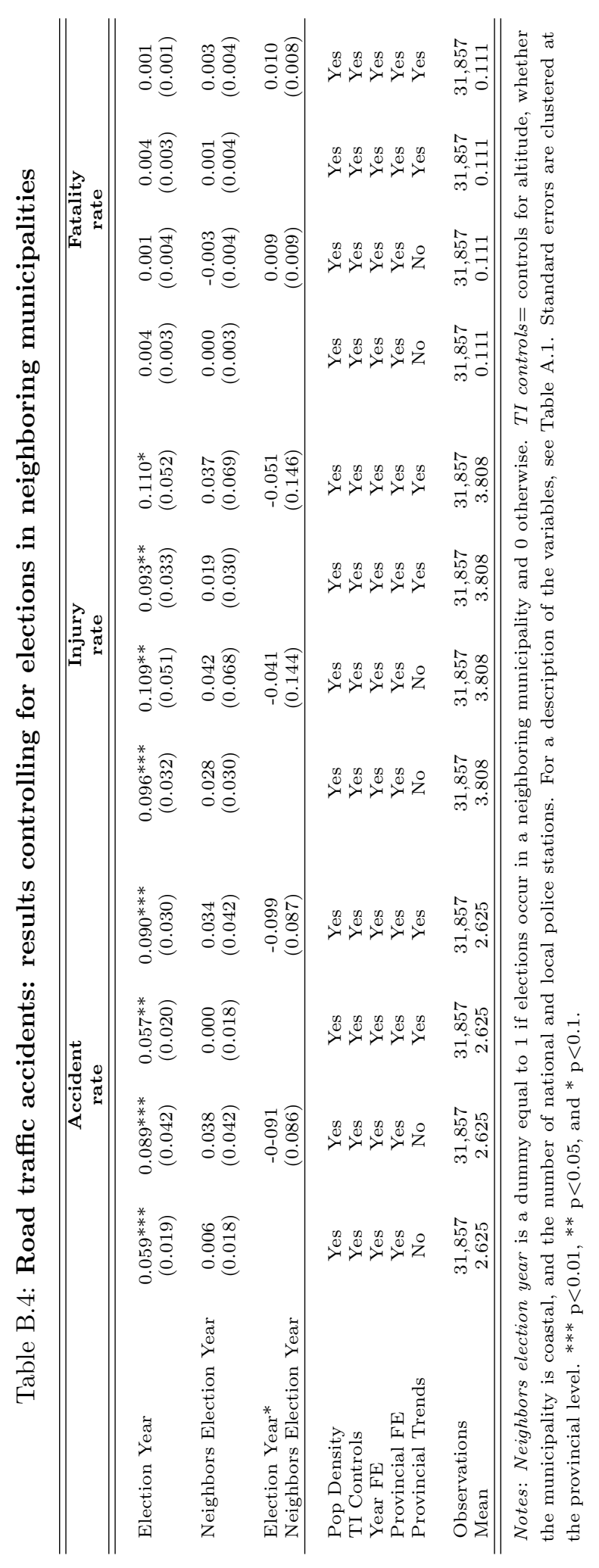

